\title{
Sprawiedliwość w sędziowskim wymiarze kary
}

\author{
JADWIGA KRÓLIKOWSKA \\ JAROSŁAW UTRAT-MILECKI
}

\author{
Europejski Ośrodek Studiów Penologicznych im. Prof. G. Rejman \\ w Zakładzie Prawnych i Społecznych Badań Integralnokulturowych \\ Wydział Stosowanych Nauk Społecznych i Resocjalizacji Uniwersytetu Warszawskiego
}

I. W polskich badaniach prawnosocjologicznych poświęconych relacji między ustawowym a sędziowskim (sądowym) wymiarem kary ważnym zagadnieniem leżącym u podstaw rozumienia pojęcia kary jest sprawiedliwość. Dokładniej rzecz ujmując, jest nim jej stawanie się jako jedno z najtrudniejszych zadań wymiaru sprawiedliwości. Jednakże sama sprawiedliwość jako temat jest nieco ukryta za problematyką poprawności ustawodawstwa, prawidłowej organizacji instytucji wymiaru sprawiedliwości i jego efektywności, oceny parametrów profesjonalizmu prawników lub charakterystyką osobowości sędziego, które to czynniki bada się w kontekście ich wpływu na decyzje sądu. Jednak w ostateczności celem wyjaśniania naukowego w obszarze tych szczegółowych zagadnień jest kwestia determinant sprawiedliwego sądzenia. To właśnie głównie o sprawiedliwość chodzi, gdy podkreśla się trudność z podejmowaniem przez sędziów decyzji. Trudność ta jest zawsze $\mathrm{w}$ jakimś stopniu zapoczątkowana probabilistycznym, a nie deterministycznym charakterem wiedzy o okolicznościach przestępstwa oraz psychospołeczną złożonością uwarunkowań działania sprawcy. Pogłębia ją świadomość powagi konsekwencji skazania oraz poddania wyroku sądu wielokrotnym, wieloaspektowym wartościowaniom przez różne podmioty.

Piszący o sprawiedliwości podkreślają jej znaczenie stwierdzeniem, że pragnienie sprawiedliwości przenika całe życie zbiorowe, a miara sprawiedliwości jest przykładana do wielu aktów społecznych jako najistotniejsza w ich ocenie. Eugène Dupréel spostrzega, że wartość sprawiedliwości bywa utożsamiana z wartością całej moralności, a więc „sprawiedliwość, która z jednej strony jest jedną 
z wielu cnót, z drugiej strony ogarnia całą moralność" . Doniosłość sprawiedliwości ukazuje się w nobilitacji tych, którzy ją czynią, oraz hańbie tych, którzy od niej odstępują. Uznanie pewnego działania lub decyzji za sprawiedliwą (wyrażone w takich sformułowaniach, jak „sprawiedliwości stało się zadość”, „,dokonał się akt sprawiedliwości dziejowej") jest potwierdzeniem uporządkowania rzeczy, wprowadzeniem rozwiązań kwestii społecznych, które znajdują aprobatę ogółu na gruncie zasad moralnych. Sprawiedliwość jest na tyle pożądaną wartością, że pod jej hasłem zmienia się nie tylko ustroje polityczne i władzę, lecz także upomina niesprawiedliwego nauczyciela czy dyskwalifikuje sędziego sportowego. Jest ważna na poziomie makro- i mikrospołecznym. Akty sprawiedliwości mają właściwości wzorcotwórcze, wprowadzają standardy w wychowaniu i modelują zachowania społeczne dorosłych obywateli. Odczucie sprawiedliwości buduje jedność społeczną, jej brak wywołuje chaos, podziały i bunt.

Sprawiedliwość jako zjawisko społeczne nie ma jedynej identyfikującej ją postaci ani nie istnieje jeden sposób, za pomocą którego się ją osiąga. Jej treść zawiera się w różnych aktach symbolicznych i działaniach praktycznych, których sens jest czytelny w języku kryteriów moralno-kulturowych danej społeczności. Sprawiedliwość może dotyczyć spraw materialnych i niematerialnych, chociaż częściej jest jednak kojarzona z kwestią równego traktowania osób z perspektywy określonych kryteriów przy dystrybucji dóbr ekonomicznych w społeczeństwie. W innych przypadkach oddanie sprawiedliwości oznacza uszanowanie, przyznanie honoru, uznanie słuszności czyjegoś postępowania. Pojęcie sprawiedliwości odnoszone jest do wielu faktów z życia społecznego i w każdym ustroju sprawą wielkiej wagi pozostaje ustanowienie zasad sprawiedliwości społecznej sensu lato $^{2}$ i zawierających się w nich zasad sprawiedliwości karnej. Kompleks tych zasad jest uwarunkowany historycznie i ideologicznie w danej społeczności. Wbrew potocznym przekonaniom nie jest on wszędzie jednakowy ani nawet stały w danej społeczności we wszystkich punktach. Toczy się wokół niego ciągła dyskusja, a jej efekty można obserwować w różnych dziedzinach życia społecznego i — co ważne - w decyzjach zapadających w strukturach wymiaru sprawiedliwości.

Naukowe badania realizowane w ramach analiz logiczno-socjologicznych na temat sprawiedliwości dystrybutywnej, a więc dotyczące głównie zasad podziału dóbr materialnych, pokazują skomplikowanie relacji między czynnikami składającymi się na efekt w postaci modelu regulacji rozdziału dóbr w danej społeczności. Dotyczy to nie tylko pozytywnego aspektu tego zjawiska (podziału dóbr i przy-

${ }^{1}$ Cyt. za: C. Perelman, O sprawiedliwości, przeł. W. Bieńkowska, słowo wstępne M. Ossowska, Warszawa 1959, s. 20; także E. Dupréel, Traktat o moralności, przeł. Z. Glinka, wstęp M. Ossowska, Warszawa 1969.

2 Wyrażenie sensu lato podkreśla, że rozumiemy tu sprawiedliwość społeczną jako ogólnospołeczną zasadę sprawiedliwości w sensie socjologicznym, a nie zasadę sprawiedliwości społecznej w rozumieniu art. 2 Konstytucji RP. 
wilejów), lecz także negatywnej strony życia (podziału dolegliwości i ciężarów). Kojarzenie sprawiedliwości z dobrami, które pozytywnie określają jakość życia, nieuchronnie wywołuje kwestię dystrybucji tak szczególnych „dóbr”, jak kary wymierzane w systemie wymiaru sprawiedliwości, które tę jakość życia pogarszają. Stosowanie sprawiedliwości rozszerza się w tym przypadku na uchybienia jako specyficzne „zasługi” determinujące karę, a pojęcia kary zasłużonej nie da się zrozumieć inaczej niż w odniesieniu do rozważań na temat kary sprawiedliwej. Ustrojowa koncepcja sprawiedliwości obejmuje obydwie kategorie faktów społecznych: nagrody i kary ${ }^{3}$.

Jest zrozumiałe, że przesłanie aksjologiczne zawarte w programie ideowym ustroju społecznego, który sankcjonuje dystrybucję dóbr w nawiązaniu do ogólnie określonych kryteriów, odnosi się też do polityki karnej państwa, a więc także struktury kar kryminalnych wymierzanych z uwzględnieniem skali zawinienia. Ustalenie aksjologicznych filarów modelu dystrybucji nie rozwiązuje raz na zawsze trudności związanych ze stosowaniem ogólnych dyrektyw w konkretnych warunkach. Realne decyzje są podejmowane w obliczu niepodzielności dóbr i komplikujących sprawę różnego typu zbiegów wartości interweniujących, które sumując się, czasem przełamują moc przyjętych zasad ogólnych. Sprawiedliwość jest nie tylko jedną ze wznioślejszych cnót wpisanych do deklaracji programowych każdego państwa, lecz przede wszystkim trudną, testowaną w praktyce sprawnością, która wymaga od ludzi zobowiązanych do jej wymierzania zaangażowania zarówno intelektu, jak i woli. Sprawiedliwość musi być nie tylko orzeczona i wymierzona, lecz także przedstawiona $\mathrm{w}$ kontekście celu oraz poszanowania powiązanych z nią norm i wartości. Zwykle nie chodzi o to, by ukazać ją społeczeństwu w postaci gotowego wyniku jakiegoś postępowania, zdefiniowanego w kategoriach sprawiedliwości. Chodzi o uwidocznienie jej jako wartości osiąganej w drodze procesu decyzyjnego, w którym wielokrotnie dokonywane są wybory angażujące w zrównoważonym stopniu wiedzę i emocje osób działających. Nade wszystko zobrazowany proces dochodzenia do sprawiedliwości ma obywatelom unaocznić obecność ładu moralnego w danej zbiorowości. $\mathrm{Z}$ tego względu wprowadzanie sprawiedliwości jest również działaniem politycznym, gdyż wiąże się z wykazywaniem się osób zarządzających zdolnością do ukształtowania i zrozumiałego przedstawienia porządku wartości stanowiących podłoże aktywności społecznych.

${ }^{3}$ Leszek Lernell słusznie podkreśla, że w sensie penologicznym kara kryminalna nie działa w systemie nagród i kar, i w tym sensie jest ona instytucją „kadłubową” (idem, Podstawowe zagadnienia penologii, Warszawa 1977, s. 11-13). Jednak w tym miejscu analizujemy system karny z perspektywy socjologicznej jako subsystem całego systemu kontroli społecznej w ramach ustroju państwowego i z tego punktu widzenia stanowi on integralny element systemu nagród i kar, którymi dysponuje społeczeństwo. 
Według Chaima Perelmana, autora dzieła $O$ sprawiedliwośs $i^{4}$, naukowe badanie zjawiska sprawiedliwości jest sprawą doniosłą ze względu na znaczenie dla społeczeństwa, które jest zainteresowane wyjaśnianiem jej istoty, zasad i sposobów osiągania w praktyce. W opinii Perelmana sprawiedliwość we wszystkich ustrojach politycznych nieprzerwanie zaprząta umysły nie tylko profesjonalistów, lecz także zwykłych ludzi. Jest z jednej strony częstym elementem deklaracji politycznych podających ją jako wartość stanowiącą podstawę porządku społecznego, a z drugiej - czymś naprawdę trudnym do osiągnięcia w świecie zróżnicowanych norm i wartości społecznych, które ją stwarzają, oraz rozmaitych kryteriów i perspektyw jej oceniania.

Ze względu na swoje znaczenie jest badawczo inspirująca dla teoretyków i analityków społecznych oraz dla praktyków, którzy w różnych dziedzinach życia ustalają i wdrażają jej zasady. Pragnienie dowiedzenia się, w czym zawiera się istota sprawiedliwości i jak może być osiągana, powoduje, że temat sprawiedliwości odżywa przy każdej okazji podziału dóbr, selekcji osób do wyróżnienia, a przede wszystkim w okolicznościach działań realizowanych w ramach wymiaru sprawiedliwości. W tej sferze jej brak wywołuje najgłębszy niepokój i dociekanie powodów nieobecności.

Naukowe badania i analizy dotyczące sprawiedliwości wciąż są przez kogoś podejmowane, proponowane są nowe ujęcia metodologiczne i teoretyczne. Rośnie świadomość znaczenia na tym polu analiz integralnokulturowych, scalających doświadczenia metodologiczno-teoretyczne i efekty empirycznych badań wielu dyscyplin ${ }^{5}$. Temat sprawiedliwości analizuje się w relacji do takich zagadnień, jak równość wobec prawa, dyskryminacja, miłosierdzie, dobro indywidualne, dobro zbiorowe, zaspokojenie potrzeb człowieka na tle kwestii korzystania z praw i wypełniania obowiązków. Badanie sprawiedliwości jako pojęcia i zjawiska społecznego należy do przedstawicieli różnych dyscyplin nauki, nie powierza się ich samemu prawu.

Współczesne badania nad sprawiedliwością są mocniej orientowane na doskonalenie procesu definiowania pojęć, wnikliwsze procedury metodologiczne porządkujące proces badawczy, a także na ściślejsze przestrzeganie logicznych reguł argumentacji przy formułowaniu wniosków. Mimo oporów z przyjmowaniem nowego typu rozumowania do zwykłych procedur sądowych, w niektórych sytuacjach sądowych ustalanie prawdy budującej podstawy sprawiedliwości wyroków opiera się na analizach logiczno-matematycznych, które nie tylko uściślają wiedzę o faktach, lecz także wzmacniają procedury weryfikacyjne i precyzują

${ }^{4}$ C. Perelman, op. cit.

5 J. Utrat-Milecki, J. Królikowska, Badania integralnokulturowe, [w:] Europejski Ośrodek Studiów Penologicznych, Uniwersytet Warszawski, Wydziat Stosowanych Nauk Społecznych i Resocjalizacji, Instytut Profilaktyki Społecznej i Resocjalizacji, Zakład Prawnych i Społecznych Badań Integralnokulturowych, red. J. Utrat-Milecki, J. Królikowska, Warszawa 2010. 
ocenę wiarygodności danych dowodowych ${ }^{6}$. W kontekście niezawisłości sędziów większą uwagę zwraca się też na rolę sądów wartościujących wypowiadanych publicznie przez osoby obdarzone autorytetem, które (podobnie jak w nauce) moga bezwiednie zakłócać obiektywizm rozstrzygnięć w procedurach wymiaru sprawiedliwości. Zgodnie z tym, co postulował Perelman, dąży się do tego, by z rozpraw naukowych odnoszących się do sprawiedliwości eliminować slogany, preferencje ideologiczne i skrótowe procedury dowodzenia, a więc by traktować ją jako zjawisko uchwytne badawczo.

Sprawiedliwość formalna, definiowana przez Chaima Perelmana jako ,zasada działania, w myśl której osoby należące do tej samej kategorii istotnej powinny być traktowane jednakowo"7, jest fundamentalna dla wymiaru sprawiedliwości. Wyrażenie ,traktować jednakowo” oznacza w tym przypadku odnoszenie się do osób należących do pewnej istotnej kategorii „tak, żeby nie można było powiedzieć, że jedna z nich została pokrzywdzona w porównaniu z drugą"8. Autor tej definicji formalnej sprawiedliwości zakłada, że ludzie stojący w obliczu prawa będą klasyfikowani do odpowiednich kategorii ze względu na charakteryzującą ich w danej chwili istotną cechę, która wiąże się z przekroczeniem norm prawa. Właśnie to pozwala na dokonanie porównania między nimi i ustalenia wspólnej normy sprawiedliwości, jaka ma być wobec nich zastosowana. Perelman stwierdza, że „sędzia jest sprawiedliwy, tzn. nieskazitelny, kiedy w tych samych sytuacjach stosuje te same prawa (in paribus causis paria jura)"9. W Normach moralnych Maria Ossowska, powołując się na Eugène Dupréela, włącza tę zasadę do grupy dyrektyw ,,z drugiego piętra”, będących regułami reguł (la régle de régles), które przełożone na język metafory matematycznej nakazują ,pod tę samą zmienną podstawić zawsze tę samą wartość"10. Nadzwyczajne znaczenie moralne dyrektyw z tego poziomu Ossowska podkreśla stwierdzeniem, że: „nieprzestrzeganie zasad sprawiedliwości dotyczącej stosowania zasad [wyr. — J.K., J.U.M.] pociąga za sobą poczucie krzywdy"l1. Jest w tej uwadze zawarte ostrzeżenie, że niesprawiedliwe traktowanie w jakiejkolwiek postaci (wyrządzanie niesprawiedli-

${ }^{6}$ Reprezentację tego kierunku badań społecznych wspomagających prawo stanowią analizy zawarte w następujących publikacjach: G. Lissowski, Porównanie zasad sprawiedliwości dystrybutywnej, „Etyka” 22, 1986, s. 153-181; idem, Zasady sprawiedliwości dystrybutywnej: nowe zasady oceny sprawiedliwości, „Studia Socjologiczne” 2011, nr 1 (200), s. 137-165; idem, Podejmowanie decyzji przez ławe przysięglych z perspektywy teorii wyboru społecznego, [w:] Prawo i ład spoteczny. Integralnokulturowa analiza zagadnienia racjonalności, red. J. Utrat-Milecki, Warszawa 2011; A. Wójtowicz, Uwagi na temat racjonalności wnioskowań w procesach poszlakowych, [w:] Kulturowe uwarunkowania polityki kryminalnej, red. M. Filar, J. Utrat-Milecki, Warszawa 2014.

${ }^{7}$ C. Perelman, op. cit., s. 37.

8 Ibidem.

9 Ibidem, s. 27.

10 M. Ossowska, Normy moralne. Próba systematyzacji, Warszawa 1985, s. 152, 227.

11 Ibidem, s. 227. 
wości lub niewprowadzanie sprawiedliwości) odciska się w ludzkiej świadomości niezwykle mocno i ma poważne konsekwencje.

W sensie ogólniejszym zasadę jednakowego traktowania można odczytywać jako wskazanie na traktowanie wszystkich jednakowo uczciwie, a więc bez tendencyjności, z rzetelnym zwróceniem uwagi na wszystkie okoliczności spraw i na właściwości sprawców. Zasada bezstronności, czyli zrównanego traktowania, nie jest samodzielna, jest posadowiona na wielu różnie skomponowanych z sobą i różnie akcentowanych wartościach tworzących podstawy systemu prawa w danym państwie. Właśnie ze względu na zaangażowanie wartości w proces oceny spraw leżących w kompetencji wymiaru sprawiedliwości zastosowanie zasady bezstronności w konkretnych sytuacjach zależy nie tylko od właściwości przedmiotowej sprawy i charakterystyki sprawcy, lecz — co wydaje się nieuniknione — także od uznawanego przez sądzącego systemu norm i wartości, jego cech charakteru i zdolności zawodowych (głównie jego prawości), niezależności sądów i uczciwości świadomie ograniczającej wpływ własnych preferencji światopoglądowych.

Powyższe uwagi wyraźnie ukazują, że czerpanie przez pojęcie sprawiedliwości znaczenia z wielu aksjologicznych źródeł komplikuje sprawę sporządzenia definicji zjawiska, która byłaby uniwersalnym przewodnikiem po rzeczywistości. Mimo pomocnej obecności zasady-dyrektywy dotyczącej jednakowego traktowania, sprawiedliwe sądzenie nie przestaje być trudnym zadaniem wymagającym zawsze indywidualnych analiz. Nie dość staranne podejście do warunku ,jednakowego traktowania", na przykład tylko wyrównanie miar kary za pewien czyn zdefiniowany jako przestępstwo i wymierzenie jej wszystkim sprawcom bez zindywidualizowanego potraktowania motywów postępowania i okoliczności spraw, naruszałoby zasadę sprawiedliwości karnej.

II. Z perspektywy kryminologicznej prawo karne jest przede wszystkim jedną z form kontroli społecznej i przynajmniej dla części kryminologów — niczym wię$\mathrm{cej}^{12}$. W nauce prawa karnego uważa się czasami, że do najstarszych funkcji prawa karnego zalicza się wymierzenie sprawiedliwości (funkcja sprawiedliwościowa) ${ }^{13}$. Natomiast w niektórych filozoficznych poglądach anglosaskich zwolenników teorii retrybutywnych na karę znajduje wyraz stanowisko, że funkcję ochronną prawa karnego najlepiej spełnić może właśnie kara sprawiedliwa ${ }^{14}$. Podejście to,

12 „Prawo karne jest więc tylko i wyłącznie jednym z elementów szerokiego spektrum instytucji i procedur składających się w każdym nowoczesnym społeczeństwie na system kontroli społecznej”, K. Krajewski, Kryminologiczne podstawy prawa karnego, [w:] System Prawa Karnego, t. 1. Zagadnienia ogólne, red. A. Marek, Warszawa 2010, s. 100.

13 „Historycznie pierwotną funkcją prawa karnego jest funkcja sprawiedliwościowa”, L. Gardocki, Prawo karne, Warszawa 2013, s. 7; por. też J. Makarewicz, Prawo karne ogólne, Kraków 1914, s. 18.

14 Por. A.P. Simester, A. von Hirsch, Crimes, Harms and Wrongs. On the Principles of Criminalisation, Oxford-Portland 2011, s. 4. 
niezależnie od powiązania z określoną tradycją imperatywnego myślenia o karze, zwraca uwagę na fakt, że efektywność wymiaru sprawiedliwości karnej jest też powiązana z jego legitymizacją ${ }^{15}$. Rozróżnienie analityczne skuteczności i zasadności karania (powiązane z podziałem na funkcję ochronną i sprawiedliwościową prawa karnego) ma więc charakter wtórny, jest wprowadzane przez badacza na potrzeby analizy danego systemu prawnego ${ }^{16}$.

Z perspektywy współczesnego polskiego ustawodawstwa nie ulega wątpliwości, że prawo karne musi pełnić przede wszystkim funkcję ochronną. Prawo z natury rzeczy musi mieć charakter celowy, prawidłowej regulacji życia społecznego na przyszłość. Przesądzają też o tym zasady dobrej legislacji. W przypadku prawa karnego jako specyficznego (sub)systemu kontroli społecznej celem nadrzędnym jest, bez wątpienia, zapobieganie przestępczości. Jednak tej prawdy nie podważa nawet tak zwana absolutna sprawiedliwościowa teoria Kanta. Nieporozumieniem jest przypisywanie temu filozofowi myśli, że zapobieganie przestępczości jest nieistotne. Nie można więc a priori uznać, że odwoływanie się do teorii kary imperatywnej (absolutnej, retrybutywnej, ,sprawiedliwej”) podważa w jakikolwiek sposób nadrzędność funkcji ochronnej prawa karnego ${ }^{17}$. Kwestię tę rozważał L.A Hart, zwracając uwagę, że wiele nieporozumień odnośnie do racjonalizacji kary wynika z pomijania w tych rozważaniach oczywistego pytania: dlaczego w ogóle niektóre zachowania ludzi są zabronione prawem jako przestępstwa? ${ }^{18}$. Zdaniem Harta głównym powodem kryminalizacji jest chęć poinformowania społeczeństwa, że określone działania nie powinny być podejmowane, a także chęć zapobieżenia ich popełnianiu, przynajmniej w pewnym stopniu. Jego zdaniem tylko przyjmując taką podstawową ideę prawa karnego, można odróżnić grzywnę od podatku. Dalej Hart wywodzi, że z różnych względów o charakterze wtórnym

15 Współcześnie aspekty teoretyczne tej kwestii analizuje Ralph Henham, Sentencing and the Legitimacy of Trial Justice, London-New York 2012.

${ }^{16}$ Zauważył to już Franz von List, por. tak zwany program marburski zawarty w artykule Der Zweckgedanke im Strafrecht, „Zeitschrift für die gesamte Strafrechtswissenschaft” 1883, nr 3, współcześnie do tej myśli wprost nawiązuje L. Gardocki, op. cit., s. 166.

17 Zagadnienie to syntetycznie przedstawia P. Chmieliński, Kanta filozofia kary, „Ius et Lex” 2006, nr 1, s. 309-322. Por. też Teorya karna Kanta ze stanowiska jego ogólnej nauki o rozumie praktycznym, [w:] Rozprawy i Sprawozdania z posiedzeń Wydziału Historyczno-Filozoficznego Akademii Umiejętności, t. XVI, w drukarni Uniwersytetu Jagiellońskiego pod zarządem Ign. Stelela, nakładem Akademii, Kraków 1883. Należy jednak przy tym zgodzić się z Andrew von Hirschem, że sam termin „teorie absolutne” nawiązujący do koncepcji religijnych przyjęty za klasyfikacją Karla Salomo Zachariae [von Liegenthal] jest niefortunny i nie powinien być stosowany w kontekście współczesnej wiedzy o społeczeństwie. Por. A. von Hirsch, Uzasadnienie istnienia i wymiaru kary we wspótczesnym retrybutywizmie, przeł. L. Schreiber, „Ius et Lex” 2006, nr 1.

18 Herbert Lionel Adolphous Hart zawarł swoje rozważania na ten temat w eseju Punishment and Responsibility. Essays in in the Philosophy of Law, wstęp J. Gardner, Oxford 2008 (ich omówienie w literaturze polskiej por. J. Utrat-Milecki, Podstawy penologii. Teoria kary, Warszawa 2006, szczególnie s. 234-251). 
wiele zachowań niepożądanych społecznie nie podlega regulacjom prawa karnego. Wskazana wyżej formuła Harta zakresu działania prawa karnego określa jedynie warunek konieczny kryminalizacji, lecz niewystarczający dla kryminalizacji. John Rawls, a za nim też Hart, wskazują na rozróżnienie podanego wyżej ogólnego powodu karania od konkretnego powodu skazania na karę kryminalną ${ }^{19}$. Pierwszy dotyczy ogólnej formuły prawa karnego, czyli odpowiedzi na pytanie, dlaczego ludzie karzą innych za określone zachowania? Zawsze w odpowiedzi powołamy się na konieczność ochrony ważnych wartości w życiu społecznym, i trudno nie uznać, że dotyczy to tych wartości w przyszłości. Natomiast jeśli pytamy, dlaczego karzemy indywidualnie oznaczoną osobę za konkretny czyn, to wtedy zawsze odpowiedź brzmi, iż jest ona winna naruszenia prawa i zasługuje na wymiar kary jej wymierzony. Nie można więc pominąć kwestii, że człowiek może być winien jedynie tego, czego już dokonał w przeszłości. Jak wskazuje Rawls — zwolennicy teorii imperatywnych kary mogliby odrzucić zasadność karania sprawców czynów typizowanych ze względu na zagrożenie, jakie stwarzają one dla społeczeństwa na przyszłość, lecz musieliby przy tym wykazać, że tak określone czyny nie zasługują na karę z perspektywy ich imperatywnie określonych zasad moralnych. Rawls wskazuje, dla ilustracji, na problem terroru. Jego zdaniem trudno stwierdzić, że typizacja zachowań prowadzących do chaosu społecznego, do rządów terroru ze względu na chęć zapobieżenia tego typu zachowaniom w przyszłości w sposób nieprzezwyciężalny kłóci się z imperatywem karania osoby dlatego, że robi coś niemoralnego. Można podobnie argumentować odnośnie do odpowiedzialności za zabójstwo w nawiązaniu do powszechnie znanego w penologii Inselbeispiel Kanta. Trudno przecież mówić, że ukaranie sprawców zabójstw, racjonalizowane instrumentalnie zapobieganiem morderstwom w przyszłości, kłóci się w sposób nieprzezwyciężalny ze stanowiskiem w sprawie karania za zabójstwo, nawiązującym do racjonalizacji imperatywnych. Karząc z przyczyn utylitarnych, nie robimy koniecznie rzeczy niemoralnych z perspektywy teorii imperatywnych.

Należy wskazać, że w tym przypadku różnica między racjonalizacją imperatywną a instrumentalną kary dotyczy jedynie sposobu uzasadnienia wymiaru kary, a nie odpowiedzi na pytanie, czy osoba może być ukarana. Odpowiedź ta może być taka sama w wielu przypadkach, niezależnie od tego, czy racjonalizować będziemy stosowanie kary, odwołując się do teorii instrumentalnych, czy imperatywnych.

Nie oznacza to ponadto (też historycznie w przypadku Kanta), że teorie imperatywne lub instrumentalne automatycznie muszą się domagać konkretnie oznaczonej kary. W obu przypadkach fakty należy wartościować. Różnica w war-

19 H.L.A. Hart, op. cit.; J. Rawls, Two Concepts of Rules, [w:] The Philosophy of Punishment. Collection of Papers, red. H.B. Acton, St Martin's 1969 (omówienie w literaturze polskiej, J. Utrat-Milecki, op. cit., s. 223-228). 
tościowaniu w teoriach imperatywnych i instrumentalnych, jak współcześnie trafnie zwraca na to uwagę A. von Hirsch, będzie dotyczyć tego, czy bierzemy pod uwagę czynniki łagodzące lub zaostrzające karę odnośnie do przeszłości (teorie imperatywne), czy odnośnie do przyszłości (prognoza kryminologiczna, teorie instrumentalne $)^{20}$. Na marginesie wskażmy tylko, że choć są to różnice zasadnicze rozumowania, w praktyce mogą prowadzić ustawodawcę i sędziego do zbliżonych wniosków, albowiem często w praktyce okoliczności obciążające i łagodzące już popełnionego czynu są jednocześnie elementami, na których buduje się negatywną lub pozytywną prognozę zachowania sprawcy w przyszłości ${ }^{21}$. Oczywiście nie zawsze tak jest. Czynniki ryzyka zachowania na przyszłość mogą też być czynnikami usprawiedliwiającymi zachowanie w przeszłości, na przykład szczególna nadpobudliwość, a więc przynajmniej w części przypadków wynik rozumowania odnośnie do wymiaru kary prowadzony w ramach filozofii imperatywnych i instrumentalnych kary może się różnić. Warto tutaj zauważyć, że wbrew potocznym przekonaniom to właśnie teorie imperatywne (retrybutywne) kary mogą przynajmniej w części przypadków ograniczać surowość karania, którą może uzasadniać instrumentalne podejście do kary ${ }^{22}$. Tak zwane względne teorie kary wcale nie są więc zawsze względniejsze dla sprawców przestępstw ${ }^{23}$. Historycznie ilustruje to teoretyczne stwierdzenie — tendencja do zaostrzania ustawowego i sędziowskiego wymiaru kary w szkole socjologicznej prawa karnego (podejście instrumentalne) w stosunku do szkoły klasycznej (podejście bardziej imperatywne). W polskich warunkach na poziomie ustawodawstwa i orzecznictwa dobrze ilustruje to zagadnienie zmiana ustawodawstwa w okresie międzywojennym i wprowadzenie ogólnie - z reguły co do wymiaru kary oraz stosowania środków zabezpieczających — surowszego kodeksu karnego z 1932 r. Współcześnie zaś szczególnie kwestia ta jest widoczna w przypadku przyjęcia przez ustawodawcę jako zasadę sądowego wymiaru kary nieprzekraczania surowością kary stopnia winy, która w nawiązaniu do koncepcji imperatywnych ma ograniczyć surowość sędziowskie-

20 Por. A. von Hirsch, Desert and Previous Convictions, [w:] Principled Sentencing. Readings on Theory and Policy, red. A. von Hirsch, A. Ashworth, Oxford 2004. Szerzej kwestie te omawiane są w pracy Previous Convictions at Sentencing. Theoretical and Applied Perspectives, red. J.V. Roberts, A. von Hirsch, Oxford-Portland 2010.

21 Por. na przykład R. Canton, Probation. Working with Offenders, London-New York 2011, s. $74-84$.

22 Por. A. von Hirsch, Seriousness, severity and the Living standard, [w:] Principled Sentencing...

23 Ten nieszczęśliwy termin z klasyfikacji między innymi powołanego K.S. Zachariae (teorie absolutne [bezwzględne]) i względne kary) jest, niestety, ciągle obecny we współczesnej nauce prawa karnego ze szkodą dla jasności prowadzonych rozważań na temat racjonalizacji kary na co zwracał uwagę A.von Hirsch, Uzasadnienie istnienia.... Por. dla ilustracji żywotności tego terminu L. Gardocki, op. cit., s. 164. 
go wymiaru kary, motywowanego między innymi potrzebami prewencji zarówno generalnej, jak i indywidualnej ${ }^{24}$.

W tej analizie należy zwrócić uwagę, że nazwa „teorie absolutne kary”, niefortunnie powtarzana w literaturze za klasyfikacją Karla Salomo Zachariae z początku XIX wieku, mylona jest czasami z odrębnym od teorii kary zagadnieniem kar bezwzględnie oznaczonych. Przyjęcie koncepcji kar bezwzględnie oznaczonych - czy to w koncepcji Monteskiusza, czy w kodeksie francuskim z $1791 \mathrm{r}$. lub bawarskim z 1813 r. (jego głównym redaktorem był Anzelm Feuerbach) — bardziej wiązało się z kwestiami ogólnoustrojowymi, pozycją władzy sądowej i niezawisłością sędziego, zakresem jego władzy dyskrecjonalnej niż z samym zagadnieniem teorii kary ${ }^{25}$. Pytanie więc o funkcję sprawiedliwościową prawa karnego nie dotyczy jego nadrzędnego celu, lecz jednej z jego podstawowych zasad, która współokreśla możliwe sposoby reagowania na przestępczość.

III. Niektórzy ze wspomnianych wyżej penologów twierdzą, że jedynie przestrzeganie nadrzędnej zasady stosowania kary sprawiedliwej pozwala na skuteczne zapobieganie przestępczości ${ }^{26}$. Argumentuje się zasadnie, że reguła ta działa także w przeciwną stronę. Trudno mówić o wymierzaniu sprawiedliwości karnej, jeśli większość sprawców jest w stanie uniknąć kary lub otrzymać kary nieproporcjonalnie małe, a najbardziej szkodliwe społecznie zachowania nie są w ogóle kryminalizowane ${ }^{27}$. Bezkarność czy banalność kary jest niesprawiedliwa w sensie imperatywnym oraz prowadzi do nieskuteczności, jeśli chodzi o zapobieganie szkodliwym zachowaniom na przyszłość. Jest więc sprzeczna zarówno z imperatywnym podejściem do kary, domagającym się proporcjonalnej odpłaty ze względu na zawinione naruszenie prawa w przeszłości, jak i jej instrumentalną racjonalizacją jako środka ograniczającego przestępczość na przyszłość.

Powołując się na Jeremy'ego Benthama, można dla ilustracji odnieść te rozważania do instrumentalnych racjonalizacji kary w tradycji utylitaryzmu anglo-

24 Por. A. Zoll, Polityka karna w kontekście obowiązu poszanowania godności osoby karanej, [w:] Kara w nauce i kulturze, red. J. Utrat-Milecki, Warszawa 2009, s. 49-53.

${ }^{25}$ Wątek ten poruszałem obszerniej w artykułach: J. Utrat-Milecki, Pozytywny sens zwrotu 'sąd wymierza karę wedtug swojego uznania', [w:] Zasada proporcjonalności w prawie karnym, red. T. Dukiet-Nagórska, Warszawa 2010; oraz Etos praw człowieka, [w:] O etyce służb społecznych, red. W. Kaczyńska, Warszawa 2010. Dla ścisłości można zauważyć, że na przykład koncepcja kary A. Feuerbacha (teoria przymusu psychologicznego) sprzyjała idei bezwzględnego oznaczenia kary, a więc dodatkowo wspierała wskazane ustrojowe uwarunkowania przyjęcia zasady bezwzględnego oznaczenia kar. Jednak szczegółowa analiza współzależności zagadnień ogólnoustrojowych i teorii kary przekracza ramy naszego opracowania. Por. też L. Lernell, op. cit., s. 112-118.

26 Por. też w szerszym ujęciu na temat znaczenia idei sprawiedliwości w życiu społecznym B. Barry, Why Social Justice Matters, Cambridge 2005, s. 169-273; a w odniesieniu do kary kryminalnej N. Christie, Granice cierpienia, przeł. L. Falandysz, Warszawa 1991.

27 Por. H. Gross, Crime and Punishment, A Concise Moral Critique, Oxford-New York 2012, s. $1-6 \mathrm{n}$. 
saskiego. Bentham łączy wprost zagadnienia sprawiedliwości i skuteczności kary, bo, według niego, jeśli kara nie jest wystarczająco surowa, aby zapobiec przestępstwu, to jest też nieusprawiedliwiona. Jego zdaniem ograniczenie praw skazanego może usprawiedliwić właśnie skuteczność w zapobieganiu przestępczości. Także zbyt surowa kara w opinii Benthama jest niesprawiedliwa w takim zakresie, w jakim jej surowość jest zbędna dla zapobiegania przestępstwom w przyszłości. Zło wynikające z dolegliwości karnej jest tylko tak długo usprawiedliwione, jak długo da się wykazać, że było odpowiednio proporcjonalnie niezbędne dla powstrzymywania przestępczości.

Jeśli więc stwierdzimy niewielką skuteczność kar dla zapobiegania przestępczości, to z tego punktu widzenia (odwrotnie niż w teoriach imperatywnych — na przykład u Kanta) należałoby w ogóle zrezygnować z karania ${ }^{28}$. Argument ten klasycznie ilustruje problem przestępczości związanej z wprowadzeniem w Stanach Zjednoczonych prohibicji w latach 20. XX wieku i późniejsze wycofanie się z tych zakazów po stwierdzeniu, że regulacja ta przynosi znacznie więcej strat niż pożytku ${ }^{29}$. Niewątpliwie więc dla zasady kary jako ultima ratio lepsze uzasadnienie dają teorie instrumentalne (utylitarne).

Należy ponownie zwrócić uwagę, że dwie wielkie tradycje kary imperatywnej i kary instrumentalnej dają się w praktyce wyróżnić przy analizie obowiązującego prawa analitycznie jedynie ex post. W praktyce większość rozwiązań prawa pozytywnego można zaliczyć (w tym — w naszym kodeksie) do tego, co określa się retrybutywizmem negatywnym, a może nawet w praktyce — bardzo szeroko rozumianą empirycznie uzasadnioną karą zasłużoną (Empirical Desert) ${ }^{30}$. Jeśli można w nawiązaniu do tych reguł budować jakąś całościową koncepcję karania, byłaby to teoria koncyliacyjna (teoria mieszana kary). W gruncie rzeczy przecież także tak zwany neoklasycyzm amerykański z lat 70. XX wieku bardziej odwoływał się do teorii instrumentalnych w duchu Benthama niż do zupełnie teoretycznie i historycznie przeciwnej mu tradycji intelektualnej Immanuela Kanta ${ }^{31}$.

Współcześnie w Polsce — od końca XX wieku — konstytucjonalizacja prawa karnego doprowadziła do jeszcze silniejszego normatywnego powiązania zasad

28 Por. J. Bentham, Wprowadzenie do zasad moralności i prawodawstwa, przeł. B. Nawroczyński, Warszawa 1958, s. 247-267 n. Rozbudowane kanony karania J. Benthama są w tym zakresie zgodne z ogólną myślą na temat celu kary i zasad jej wymiaru we wcześniejszym klasycznym dziele Cesarego Beccarii, O przestępstwa i karach, przeł. E. Rappaport, wstęp S. Lelental, Łódź 2014, s. 88.

29 Por. podobnie A.P. Simester, A. von Hirsch, op. cit., s. 209.

30 Por. A. Zoll, op. cit., s. 52, o pojęciu retrybutywizmu negatywnego, J. Utrat-Milecki, Kara. Teoria i kultura penalna: analiza integralnokulturowa, Warszawa 2010, s. 63-64; o pojęciu kary empirycznie zasłużonej por. P.H. Robinson, Distributive Principles of Criminal Law. Who Should be Punished How Much, Oxford-New York 2009, s. 139-140 i 175-212.

31 Por. podobnie K. Krajewski, Kryminologiczne podstawy prawa karnego, [w:] System Prawa Karnego, t. 1, s. 133. 
prawa karnego z ogólnymi zasadami ustrojowymi ${ }^{32}$. Prawo karne wypełnia swoje funkcje w określonych warunkach ustrojowych, które narzucają odpowiednio zasady, jakimi należy się kierować także w toku realizacji funkcji ochronnej prawa karnego. Niezależnie od tych metauwarunkowań konstytucyjnych i prawnomiędzynarodowych legitymizmu prawa karnego, także wewnętrzne zasady jego działania nie dadzą się sprowadzić wyłącznie do skuteczności. Dla najprostszej ilustracji wystarczy wskazać na zasady sędziowskiego wymiaru kary z art. 53 k.k. Artykuł ten zawiera podstawową dla ochrony wolności i praw człowieka, wspomnianą już wyżej zasadę, że ingerencja karna nie może być dolegliwa ponad stopień winy. Stopień winy odnosi się zaś do zarzucalności czynu popełnionego w przeszłości, a nie do spekulacji na temat przyszłych zachowań. Stopień winy nie jest więc mierzony skutecznością wymierzonej kary odnośnie do zapobiegania przestępczości na przyszłość 33 . Podobnie art. 53 k.k. wyraża specyficzną dla prawa karnego zasadę proporcjonalności dolegliwości do szkodliwości już popełnionego czynu, a nie proporcjonalności kary do szkodliwości czynów, które mogłyby być, z większym lub mniejszym prawdopodobieństwem, popełnione przez kogokolwiek w przyszłości. Artykuł 53 k.k. powołuje się też przy określaniu zasad sądowego wymiaru kary na zasadę kształtowania świadomości prawnej społeczeństwa. Ma się ona opierać na poszanowaniu niezbywalnej przyrodzonej godności ludzkiej, która dotyczy też przecież osób skazanych za popełnienie nawet najpoważniejszych przestępstw. Odwołuje się z pewnością nie tylko do wyników badań na temat skuteczności zniechęcania do przestępstwa, lecz odpowiednio także do aksjologii konstytucyjnej, która jest autonomiczna w stosunku do spekulacji o oddziaływaniu sankcji na przyszłośćc ${ }^{34}$. Dlatego mówimy w odniesieniu do tej zasady, że jest to prewencja generalna (ogólna) pozytywna, integrująca, a jej adresatem jest ogół społeczeństwa, który nie rozważał popełnienia przestępstwa, a nie jedynie osoby, które mają być odstraszone od popełniania przestępstw surowością sankcji.

Powiązanie kary kryminalnej z popełnionym czynem (traktowanym przez Lernella słusznie jako integralny element struktury kary kryminalnej) $)^{35}$ pełni fundamentalną rolę w ramach funkcji gwarancyjnej prawa karnego. Stąd nie dziwi

32 Por. więcej A. Zoll, Konstytucyjne aspekty prawa karnego, [w:] System Prawa Karnego, t. 2. Źródła prawa karnego, red. T. Bojarski, Warszawa 2011, s. 219-266.

33 Ciekawym problemem teoretycznym jest odniesienie tej zasady do specyficznych kategorii sprawców, w tym recydywistów. Postulat powszechnego stosowania tej zasady także wobec specyficznych kategorii sprawców i wskazanie na teoretyczne i dogmatyczne podstawy jego realizacji w nauce prawa karnego poświęcone jest odrębne opracowanie J. Utrat-Mileckiego, Zasady sąowego wymiaru kary wobec przestępców niebezpiecznych, [w:] Dlugoterminowe kary pozbawienia wolności, red. W. Zalewski, Gdańsk 2015, s. 149-181.

34 Odwołuje się więc do art. 30 Konstytucji, a na tej podstawie formułowana jest też wprost zasada humanitaryzmu karania (art. 3 k.k.); por. też A. Zoll, Polityka karna ..., s. 46-47.

35 L. Lernell, op. cit., s. 28-29. 
też ranga zasady nullum crimen sine lege poenali anteriori w międzynarodowych standardach praw człowieka czy w konstytucji. Jak widać w tych rozważaniach - odejście $\mathrm{w}$ niektórych koncepcjach i rozwiązaniach prawa pozytywnego od klasycznego ujęcia zagadnienia kary kryminalnej (wszystko jedno - imperatywnego czy instrumentalnego) musi prowadzić do istotnego problemu określenia na nowo racjonalizacji daleko idącej ingerencji w prawa i wolności osoby skazanej.

Karygodny czyn popełniony przez sprawcę wiąże stosowanie represji z wolnością człowieka. W jakimś sensie, choćby tylko filozofii praktycznej w duchu Immanuela Kanta, uzależnia możliwość stosowania represji od określonych decyzji sprawcy, a więc w tym sensie zachowuje poszanowanie dla jego wolności. W filozofii kary najdobitniej wyrażała to klasyczna koncepcja kary Hegla ${ }^{36}$, w analizie bardziej współczesnych zasad prawa karnego wykorzystana przez F. Doyla ${ }^{37}$.

Sprawca nie ma wpływu lub ma wpływ bardzo niewielki na to, jaką diagnozę postawi mu biegły w procesie karnym. Natomiast może, nawet wbrew stwierdzonym czynnikom ryzyka, podjąć trud powstrzymania się od zachowań, do których zgodnie z daną ekspertyzą ma ponadprzeciętne skłonności. Może być przecież i tak, że w przyszłości to właśnie diagnozujący biegły popełni przestępstwo, którego podwyższone ryzyko diagnozował u skazanego. Znamy też z doświadczenia sądowego przypadki biegłych (w tym w zakresie przestępstw pedofilnych lub z użyciem przemocy), którzy później sami byli skazywani za podobne przestępstwa. W przypadku wyceny ryzyka określonego zachowania sprawcy w przyszłości to inni ludzie decydują, czy ktoś zasługuje na wolność. Nie wynika to już z decyzji jednostki, która ma przecież, zgodnie z koncepcją teoretyczną, wolność przyrodzoną, a nie daną jej przez społeczeństwo.

Powiązanie stosowania prawa karnego z odpowiedzialnością karną opartą na zarzucalności popełnionego czynu jako podstawie materialnej kary w ramach zasady nullum poena sine lege stanowi fundament gwarancyjnej funkcji prawa karnego. Jest niejako zewnętrznym wobec samej kary (jej struktury wewnętrznej w terminologii Lernella) ${ }^{38}$ aspektem sprawiedliwościowym kary. Oparcie stosowania represji na przesłankach nawiązujących do określonych diagnoz przyszłego zachowania, określanych z różnym stopniem prawdopodobieństwa, podważa wolność jednostki. Jest to szczególnie kontrowersyjne w przypadku, gdy osoba zostaje najpierw uznana za zdolną do ponoszenia odpowiedzialności za swoje czyny i skazana za zarzucane jej przestępstwo, a następnie uznaje się prawo grupy społecznej (organów państwa) do jej represjonowania na podstawie diagnoz ewentualnego zagrożenia $\mathrm{z}$ jej strony w przyszłości. W tym przypadku hipotetycznie określone zdarzenie abstrakcyjne, przyszłe i niepewne, staje się podstawą do zastosowania konkretnie określonej represji wobec indywidualnie oznaczonej osoby

36 Por. jej syntetyczne krytyczne omówienie ibidem, s. 70-83.

37 Omówienie poglądów Doyle’a zob. J. Utrat-Milecki, Podstawy penologii..., s. 232-234.

38 Por. L. Lernell, op. cit., s. 28-29. 
(system represji dwutorowej lub na przykład współczesny anglosaski system sankcji karnych względnie nieoznaczonych ${ }^{39}$. Kwestia zasadności tego rodzaju działań represyjnych, przede wszystkim pozbawiania jednej z najważniejszych wartości konstytucyjnych, jaką jest wolność człowieka, musi być już oceniana z uwzględnieniem konstytucyjnej zasady proporcjonalności. Nie jest to już proporcjonalność mierzona, jak w klasycznych teoriach kary imperatywnej czy instrumentalnej, odniesieniem do szkodliwego zachowania w przeszłości i zarzucalnością tego czynu (winy). W tym przypadku badamy proporcjonalność między ryzykiem zamachu w przyszłości na określone dobra chronione prawem a ograniczaniem praw i wolności danej jednostki w celu jego redukcji. W tym przypadku, inaczej niż w klasycznym ujęciu kary, każda ingerencja w prawa człowieka skazanego, nieuzasadniona proporcjonalną ochroną istotnych dóbr prawnych w przyszłości przed działaniem tej jednostki, musi być uznana za niekonstytucyjną. Dlatego też w pełni zasadny jest postulat Wojciecha Zalewskiego, aby w przypadku takiej sankcji postpenalnej nawet wobec sprawców najpoważniejszych przestępstw stosować co do zasady wyłącznie środki uzasadnione proporcjonalnie koniecznością ograniczenia ryzyka bez pozbawiania istoty wolności, jaką jest swoboda poruszania się. Wydaje się zasadne, aby w takim przypadku wyłączać — przynajmniej co do zasady — stosowanie faktycznego bezwzględnego pozbawienia wolności jako środka zabezpieczającego. Jeśli jest to naprawdę uzasadnione diagnozowanym poziomem ryzyka, należy podjąć inne kontrolne działania postpenalne z wykorzystaniem odpowiednich czynności operacyjnych, w niektórych przypadkach z uwzględnieniem stosowania monitoringu elektronicznego ${ }^{40}$.

Ta uwaga nie dotyczy oczywistych przypadków izolacji medycznie uzasadnionej, w szczególności tych, do których odnosi się ustawa o ochronie zdrowia psychicznego. Jednak właśnie kategoria osób, o których mówimy, rozważając środki postpenalne (lub sankcje względnie nieoznaczone dla sprawców poważnych przestępstw z użyciem przemocy — na przykład w systemie brytyjskim), z reguły nie kwalifikuje się do zastosowania odpowiedniej ustawy o ochronie zdrowia psychicznego w nawiązaniu do zasad związanych jedynie z wiedzą medyczną (psychiatryczną).

Środki zabezpieczające orzekane wobec sprawców czynów zabronionych pod groźbą kary kryminalnej powinny być orzekane z poszanowaniem czterech zasad podstawowych, nawiązujących zarówno do wiedzy medycznej, jak i przede wszystkim kryminologicznej wyceny ryzyka recydywy, a mianowicie: niezbędno-

39 Odnośnie do systemu brytyjskiego por. S. Easton, Ch. Piper, Sentencing and Punishment. The Quest for Justice, Oxford-New York 2008, s. 151-165 n. Problematykę zaliczam w innym miejscu do odrębnej kategorii klasyfikacyjnej koncepcji penologicznych tak zwanego negatywizmu penalnego (Kara. Teoria i kultura penalna, s. 89-100).

40 Por. W. Zalewski, Przestepca ,niepoprawny” - jako problem polityki kryminalnej, Gdańsk 2010, s. 400-401. 
ści (konieczności), proporcjonalności, obligatoryjności i wysłuchania biegłych ${ }^{41}$. Ich podstawą jest więc prewencja indywidualna poprzez uniemożliwianie popełniania jednostce czynów zabronionych w przyszłości, stosowana dla ochrony społeczeństwa (protection of society). Ideologiczną podstawą jest przekonanie, że mamy prawo diagnozować sprawcę jako stwarzającego ryzyko i na tej podstawie stosować dolegliwe środki, w tym pełną izolację, gdyż popełnił czyn zabroniony. Należy zauważyć, że ta gwarancyjna zasada konstytucyjna stosowania środków zabezpieczających przewidzianych prawem karnym (zasada nullum crimen sine lege poenali anteriori) ma zastosowanie nie tylko w odniesieniu do postpenalnych środków zabezpieczających, lecz także do stosowania środków zabezpieczających wobec sprawców uznanych za niepoczytalnych w chwili popełnienia czynu zabronionego pod groźbą kary kryminalnej. Także w tym przypadku zastosowanie środka zabezpieczającego możliwe jest jedynie w ramach zasad odpowiedzialności karnej po sądowym ustaleniu popełnienia zarzucanego czynu (przynajmniej w zakresie strony przedmiotowej opisu danego zachowania). Różnica dotyczy tylko wyłączenia w tym drugim przypadku winy, co implikuje, że czyn zabroniony nie jest przestępstwem, a więc w tym przypadku wyłączona jest możliwość wymierzenia kary kryminalnej. W przypadkach stwierdzenia niepoczytalności sprawcy, które wyklucza przypisanie winy i uniemożliwia skazanie sprawcy na karę kryminalną środek zabezpieczający — w tym polegający na przymusowej pełnej izolacji od społeczeństwa - stanowi jedyne narzędzie realizacji funkcji ochronnej prawa karnego. Jego orzeczenie musi być jednak uzasadnione wyłącznie ryzykiem podobnie niebezpiecznych zachowań w przyszłości, co wyklucza jego zastosowanie, gdy takiego ryzyka nie da się stwierdzić. I tak — dla ilustracji problemu - dokonanie nawet najokrutniejszych mordów pod wpływem nieświadomego zażycia przez sprawcę podstępnie zaaplikowanych mu przez kogoś środków zmieniających świadomość nie pozwala ani na ukaranie sprawcy okrutnych mordów, ani nie uzasadnia zastosowania wobec niego środków zabezpieczających, jeśli biegli nie stwierdzą ryzyka powtórzenia się owego sztucznie wywołanego stanu morderczego amoku ${ }^{42}$. Zastosowanie i czas trwania oraz sposób realizacji środka zabezpieczającego nie może być określony z góry, bo choć podstawą jego stosowania było stwierdzenie popełnienia czynu zabronionego, to zasadność jego zastosowania i jego wymiar zależeć będą jedynie od diagnozy stanu niebezpieczności sprawcy na przyszłość.

41 Por. J. Gierowski, L. Paprzycki, Środki zabezpieczajace: umieszczenie w zamkniętym odpowiednim zaktadzie psychiatrycznym, w zakładzie karnym, w zakładzie zamkniętym przeznaczonym dla sprawców przestępstw skierowanych przeciwko wolności seksualnej popetnionych w zwiazku z zaburzeniami preferencji seksualnych albo skierowania takich sprawców na leczenie ambulatoryjne, [w:] System Prawa Karnego, t. 7. Środki zabezpieczajace, red. L. Paprzycki, Warszawa 2012, s. 140 n.

${ }^{42} \mathrm{~W}$ przypadku gdy sprawca sam wprawił się w stan nietrzeźwości, z reguły jego wina, a więc i możliwość orzeczenia kary nie zostają wyłączone (por. art. $31 \S 3$ k.k.). 
IV. Nie jest przedmiotem artykułu ustosunkowanie się do złożonej prawnokarnej i konstytucyjnej analizy kontrowersyjnych rozwiązań współczesnego prawa karnego. Należy jednak wskazać, że kwestia zasad stosowania prawa karnego wiąże się bezspornie mocno także z zagadnieniem sprawiedliwości, a więc oddaniem każdemu tego, co mu się należy, w tym usprawiedliwieniem przez grupę społeczną nadzwyczajnego pozbawiania danej jednostki określonych praw. W połowie XX wieku zagadnienie to podjął od strony teoretycznej w świetnym eseju John Rawls ${ }^{43}$. Zwrócił uwagę, że instytucja kary kryminalnej, która wymaga, aby jedynie winny poniósł karę, pełni fundamentalną rolę gwarancyjną dla praw człowieka. Odejście od tej zasady powoduje, że racjonalizacja represji karnej (co jest pojęciem szerszym niż samo usprawiedliwienie) musi się odwoływać do argumentacji innej niż ta, którą stosujemy w przypadku kary kryminalnej. W jego analizie ilustracją rozważań było badanie hipotetycznego wprowadzenia do ustawodawstwa nowej instytucji tak zwanego sądowego pomówienia. Opisywał abstrakcyjny przypadek skazania niewinnego wybranego w specjalnej procedurze. Taki wybór „zastępczego" skazanego miano by stosować, gdy nie można odnaleźć prawdziwego sprawcy, a ukaranie kogokolwiek za bulwersujący społecznie czyn wydaje się uzasadnione, bo rozładuje napięcia społeczne i być może odstraszy potencjalnych sprawców na przyszłość. Rawls zwraca jednak uwagę, że odstraszenie czy rozładowywanie napięć jako funkcja prawa karnego występuje właśnie dlatego, że karzemy rzeczywistego sprawcę skazanego na karę postrzeganą jako sprawiedliwa. Natomiast takie rozwiązanie jak skazanie na pokaz niewinnego może działać jedynie jako nielegalna praktyka, gdy nikt nie wie, że jest to osoba niewinna. Jako instytucja obowiązującego prawa zapewne nie dałoby się tego rozwiązania pogodzić z podstawowymi zasadami ustroju demokratycznego i prawami człowieka zapisanymi w konstytucji i aktach prawa międzynarodowego. Ponadto, takie rozwiązanie prawne nie spełniałoby swoich funkcji odstraszania od przestępstwa, skoro byłoby wiadomo, że skazany nie musiał popełnić przestępstwa i został jedynie wybrany losowo jako kozioł ofiarny spośród osób, które tylko potencjalnie mogły się danego czynu dopuścić. Zgodnie z tą logiką tak zwane przetrzymywanie osób, które służby specjalne kwalifikują jako terrorystów (jak w Guantanamo), nie odstrasza terrorystów, skoro większości osób tam osadzonych nawet nie postawiono zarzutów z tytułu działalności terrorystycznej. Przeciwnie, samo represjonowanie osób niewinnych, wzbudzając poczucie rażącej niesprawiedliwości w niektórych środowiskach, ułatwia rekrutację przyszłych terrorystów. Działania takie podważają legitymizm władzy przetrzymującej, która sama zaczyna być postrzegana jako stosująca terror. Instytucja tego rodzaju nie tylko jest sprzeczna z podstawowymi, ukształtowanymi historycznie — szczególnie od czasów Oświe-

43 J. Rawls, op. cit., s. 105-114; omówione w lit. polskiej J. Utrat-Milecki, Podstawy penologii..., s. 223-228. 
cenia — zasadami odpowiedzialności karnej, lecz ponadto podważa legitymizm władzy odwołującej się do demokracji i praw człowieka.

Sprawa oceny zachowań władzy komplikuje się, gdy ewentualne wymierzenie kary ponad stopień winy i wysokość szkody dotyczy sprawcy, który wprawdzie nie zasługuje na określoną dolegliwość, lecz jednak w ogóle naruszył prawo. Wydaje się, że stygmatyzacja, jaka wynika z wymierzenia kary kryminalnej sprawcy, ułatwia później społeczną akceptację bardziej liberalnego stosowania wobec tych osób dolegliwych środków chroniących społeczeństwo. Nie akceptowanoby tak łatwo stosowania tego rodzaju środków wobec osób wcześniej niekaranych tylko dlatego, że jakiś ekspert czy instytucja sugerują podwyższone ryzyko zachowań przestępczych z ich strony w przyszłości. Wydaje się, że nie zawsze w analizach środków postpenalnych dostatecznie bierze się pod uwagę ten argument socjologiczny.

Tymczasem, jak się zdaje, współcześnie wobec części sprawców przestępstw te odczucia społeczne stają się elementem wykorzystywanym dla usprawiedliwiania wprowadzania innych niż kara drastycznych środków walki z przestępczością, niezależnie od kontrowersyjnych, naukowych i pseudonaukowych argumentów na rzecz ich stosowania. Mechanizm ten dobrze ilustruje debata na temat tak zwanej ustawy o bestiach w polskich środowiskach naukowych - prawniczych, kryminologicznych i psychiatrycznych ${ }^{44}$. Wprowadza się tego rodzaju środki z przekonaniem, że drastyczne metody ograniczania praw i wolności nie dotyczą jednak wszystkich jednostek, a jedynie specjalnej klasy osób - klasy stworzonej z iloczynu zbiorów osób, które - po pierwsze - wcześniej popełniły czyn zabroniony pod groźbą kary kryminalnej, z powodu którego są też społecznie negatywnie postrzegane, a po drugie - mają zdiagnozowane specjalne właściwości, zwiększające statystycznie prawdopodobieństwo powtórzenia podobnego czynu — w szczególności z użyciem przemocy lub związanego z zaburzeniami seksualnymi. Wyróżnianiu tej klasy osób współcześnie sprzyjają zmiany cywilizacyjne związane z większą wrażliwością na los ofiar przestępstw. Sprzyja im pluralizm dyskursu oddolnego na temat przestępczości (na przykład poprzez internet), rozwój tak zwanego społeczeństwa ryzyka, ograniczenie koncepcji państwa dobrobytu ${ }^{45}$. W rozwoju środków skierowanych na represjonowanie osób zaliczonych do tej kategorii dużą rolę odgrywa nowy pozytywizm. W jego ramach powraca przekonanie wśród niektórych ekspertów o rzekomej możliwości bardzo precy-

44 Por. praca magisterska Marty Adaszewskiej napisana pod kierunkiem Jarosława Utrat-Mileckiego, pt. Z zagadnień środków zabezpieczajacych. Ujęcie problemu w kontekście dyskusji o aktualnych reformach polskiego prawa karnego, (IPSiR UW 2014, niepublikowana), s. 59-78.

45 Więcej i z dalszą literaturą zob. J. Utrat-Milecki, Penologia integralnokulturowa: zarys problematyki, [w:] Kara w nauce i kulturze, s. 229-266. Por. też J. Simon, Governing Through Crime. How the War on Crime Transformed American Democracy and Created a Culture of Fear, Oxford-New York 2007. 
zyjnego naukowego przewidywania przyszłych zachowań jednostki ludzkiej (evidence based policy). W tych koncepcjach eksperci odwołują się przede wszystkim do faktów, a nie do aksjologii konstytucyjnej, która jedynie ogranicza zewnętrznie możliwość kształtowania owej dyskusyjnej evidence based policy. Niezależnie od wyrażanych wątpliwości co do faktycznej zdolności nauki do precyzyjnego przewidywania przyszłych wyborów jednostki, sama idea oparcia interwencji, rzekomo, jedynie na faktach wydaje się mało precyzyjna. Każda faktyczna diagnoza musi następnie podlegać wartościowaniu, jeśli staje się podstawą działania. Zwolennicy tych nurtów nie tyle więc odchodzą w ogóle od moralności i wartościowania, ile zmieniają akcenty moralne i — być może — system wartości. Ich zasady moralne wyrażane są technokratycznym językiem nowej penologii, jednak wyraźnie określa się w nim aksjologiczne preferencje — na przykład co do oceny relacji między prawami człowieka a interesem grupy społecznej czy raczej ośrodka władzy, który za „rozsądną cenę” ma zarządzać grupą ${ }^{46}$.

W tych uwarunkowaniach współczesnej dyskusji na temat przestępczości zagadnienie sprawiedliwości wydaje się nie w pełni doceniane nawet w literaturze naukowej. Tak zwana nowa penologia, różne podejścia menedżerskie mówiące o „zarządzaniu przestępczością”, wycenie ryzyka itp., w dużym stopniu już przez wyjściowe zdefiniowanie problemu ograniczają pole do analizy funkcji sprawiedliwościowej prawa karnego. W rozważaniach zdecydowanie dominuje kwestia skuteczności zapobiegania przestępczości. Jednak błędem jest uznanie, że jeśli o czymś w nauce nie mówimy, to tego nie ma. Problem sprawiedliwości, nawet jeśli nieopisywany, niewątpliwie dla wymiaru sprawiedliwości karnej pozostaje centralny. Nie jest więc właściwe, że rozważania o sprawiedliwości koncentrują się przede wszystkim wycinkowo coraz częściej na analizie potencjalnych zagrożeń niewinnych ofiar, kosztochłonności reakcji karnej i ewentualnie ustrojowej konieczności przestrzegania pewnych minimalnych, zewnętrznych wobec prawa karnego, standardów konstytucyjnych i prawnomiędzynarodowych.

Odnośnie do trudnej do badania kwestii sprawiedliwości kary warto wskazać na istotną ciągle myśl Anthony’ego M. Quintona. Już wiele lat temu badacz ten w konwencji filozofii analitycznej argumentował, że pojęcie kary sprawiedliwej jest pleonazmem, bo przecież sędzia nie może wymierzyć kary niesprawiedliwej ${ }^{47}$.

46 Dobre i wyważone omówienie tej kwestii zawiera też praca umiarkowanego zwolennika humanitarnego stosowania nowych narzędzi wyceny ryzyka Mariusza Sztuki, Anachronizm i aktualność. Idea resocjalizacji w sporze o nowoczesność, Kraków 2013. Por. też uwagi do tej pracy J. Utrat-Milecki, [rec.] Aktualność programu profilaktyki społecznej i resocjalizacji na Uniwersytecie Warszawskim. Refleksje wokół ksiązki Anachronizm i aktualność. Idea resocjalizacji w sporze o nowoczesność, M. Sztuka, Kraków 2013, „Profilaktyka Społeczna i Resocjalizacja” 25, 2015, s. 163-179.

47 Por. A.M. Quinton, On Punishment, [w:] The Philosophy of Punishment..., s. 55-64; omówienie tych poglądów w polskiej lit. J. Utrat-Milecki, Podstawy penologii..., s. 219-221. 
Wskazywał, że wypowiedź sędziego „skazuję X na karę niesprawiedliwą” jest niemożliwa na gruncie ogólnych reguł językowych stosowanych do opisu tego, co robi sędzia, gdy wymierza sprawiedliwość karną. Taki zwrot jako element wypowiedzi performatywnej sędziego byłby świadectwem, że to, co robi sędzia, jest bezprawne, bo nie wolno mu skazywać nikogo na karę niesprawiedliwą lub też takie stwierdzenie sędziego byłoby językowym nieporozumieniem. Jednocześnie Quinton zwraca uwagę, że zupełnie inna jest sytuacja, gdy zwrot „X skazano na karę niesprawiedliwą" stosowany jest do opisu i oceny określonego działania sądu, a więc gdy stanowi element wypowiedzi deskryptywnej, a nie performatywnej. Mam prawo jako obserwator życia społecznego i rozwiązań prawnych oceniać je jako sprawiedliwe lub niesprawiedliwe, natomiast sędzia nie może skazać nikogo na karę niesprawiedliwą. W szerszej perspektywie zagadnienie to wiąże się z problemem ustawowego bezprawia w rozumieniu filozofii prawa późnego Gustava Radbrucha ${ }^{48}$. W przypadku stwierdzenia niesprawiedliwości kary mamy do czynienia ze swoistą funkcjonalnokrytyczną interpretacją rozwiązań de lege lata i orzecznictwa prowadzoną z metaperspektywy ${ }^{49}$. Takie krytyczne spojrzenie jest niezwykle ważne - zarówno dla prawa, jak i naukowej analizy podstaw karania - może prowadzić też do wniosków de lege ferenda. Natomiast w praktyce sędziowskiej w toku wyrokowania może być znacznie bardziej problematyczne, gdyż analizy sędziego nie mogą zasadniczo prowadzić do podważania zarówno treści obowiązujących przepisów, jak i ogólnych założeń aksjologicznych przyjętych zasad sądowego wymiaru kary. Jest to więc problem szczególnie wyeksponowany w naszej cywilizacji po raz pierwszy przez Sofoklesa w tragedii Antygony. Przewijał się też wielokrotnie w badaniach sędziowskiego wymiaru kary, prowadzonych przez Bronisława Wróblewskiego i Witolda Świdę ${ }^{50}$ oraz Tomasza Kaczmarka ${ }^{51}$, a ostatnio w badaniach zespołu Zakładu Prawnych i Społecznych Badań Integralnokulturowych IPSiR UW realizowanych w ramach grantu Narodowego

48 Mam na myśli jego lapidarny tekst, który wywarł jednak szeroki wpływ na filozofię i teorię prawa, zwłaszcza w nauce niemieckiej, pt. Ustawowe bezprawie i ponadustawowe prawo, [w:] G. Radbruch, Filozofia prawa, przeł. E. Nowak, przedmowa J. Zajadło, R. Dreier, S.L. Paulson, Warszawa 2012, s. 244-254.

49 Funkcjonalnokrytyczna wykładnia pozwala na odnoszenie analizy przepisów do wartości (dóbr prawnych), które te przepisy mają ochraniać, dlatego można ją określić jako metaanalizę. Por. C.C. Lauterwein, The Limits of Criminal Law. A Comparative Analysis of Approaches to legal Theorizing, Surrey-Burlington 2010, s. 9-10; por. też opracowanie J. Utrat-Milecki, Prawo karne i polityka kryminalna jako podsystem kontroli społecznej. Analiza integralnokulturowa, [w:] Kulturowe uwarunkowania polityki..., s. 89-91 n.

50 B. Wróblewski, W. Świda, Sędziowski wymiar kary w Rzeczypospolitej Polskiej. Ankieta, Wilno 1939; B. Wróblewski, Sprawność i prawnicza kultura umysłowa sędziów karnych, „Rocznik Prawniczy Wileński” 10, 1939.

51 T. Kaczmarek, Sędziowski wymiar kary w Polskiej Rzeczypospolitej Ludowej w świetle badań ankietowych, Wrocław 1972. 
Centrum Nauki ${ }^{52}$. Współcześnie ze szczególną intensywnością dotyczyć może na przykład kwestii świadka koronnego oraz skazania w warunkach art. 60 § k.k., a także nabiera nowego wymiaru w świetle instytucji dobrowolnego poddania się karze i skazania bez rozprawy.

V. Rozważając zagadnienie sprawiedliwości w prawie karnym, należy zauważyć za Leszkiem Lernellem, że istnieje zasadnicza różnica między tradycyjną zasadą odpłaty dobrem za dobro a zasadą odpłaty złem za zło ${ }^{53}$. Powszechnie przyjmuje się, nawet na poziomie teorii społeczeństwa, że życie społeczne w dużym stopniu odwołuje się do zasady do ut des (,daję, abyś dał”). W tym sensie już najbardziej podstawowe zasady życia społecznego wskazują na ogólną zasadność reguły wynagradzania dobrem za dobro (socjologiczne teorie wymiany). W przypadku karania mamy jednak odmienną sytuację. Kara jest zawsze zadaniem dolegliwości i w tym sensie, szczególnie w społeczeństwach odwołujących się do praw człowieka, jest postrzegana jako zła, gdyż jest dolegliwością traktowaną jako odpłata za inne złe zachowanie, czyli przestępstwo ${ }^{54}$. Tego rodzaju odpłata budzi poważne wątpliwości i jest odległa od norm — na przykład chrześcijańskiego ideału zawierającego wezwanie ,zło dobrem zwyciężaj”.

W okresie nowożytnym - lecz odpowiednio również w przeszłości — podważano moralność kary właśnie dlatego, że postrzega się ją jako idę odpłaty złem za zło. Uważano, że taka odpłata nigdy nie jest uzasadniona, a więc jeśli zadanie dolegliwości (na przykład pozbawienie wolności) nie jest absolutnie konieczne dla ochrony dóbr w przyszłości, to nie jest usprawiedliwione ${ }^{55}$. Kwestionowanie kary prowadzi do poszukiwania jej alternatyw. Mogą to być różne formy zadośćuczynienia materialnego i duchowego za wyrządzoną krzywdę (sprawiedliwość naprawcza, na przykład w ramach mediacji) lub też stosowanie środków o charakterze stricte zabezpieczającym, których ratio legis i usprawiedliwienie etyczne ma charakter wyłącznie prewencyjny. Jak jednak pisał — naszym zdaniem traf-

52 Program Badawczy NCN, Kultury penalne. Kontekst kulturowy polityki kryminalnej i reform prawa karnego. Analiza prawno-penologiczna, historyczna, socjologiczna i kulturowa (antropologiczna) reform prawa karnego $w$ Polsce na tle tendencji europejskich $i$ światowych (dec. Nr DEC-2011/01/B/HS5/03206, kierownik całości J. Utrat-Milecki, części socjologicznej (w tym badań ankietowych i badań jakościowych sędziów, prokuratorów i kuratorów zawodowych) Jadwiga Królikowska.

53 Por. L. Lernell, op. cit., s. 59.

54 Por. ibidem, s. 123, gdzie omawia koncepcję Benthama. Jest to ogólnie widoczne w nowożytnej myśli anglosaskiej od czasów Tomasza Hobbesa, który pisał „kara jest to zło zadane przez władzę publiczną temu, kto uczynił lub zaniechał czegoś, co ta władza uważa za przekroczenie prawa, przy tym zadane w tym celu, by wola ludzi była dzięki bardziej gotowa do posłuchu", Lewiatan, czyli materia, forma i władza państwa kościelnego i świeckiego, przeł. C. Znamierowski, Warszawa 1954, s. 276.

55 Por. N. Christie, op. cit.; T. Mathiesen, Prison on Trial, Winchester 2006; V. Ruggiero, Penal Abolitionism, Oxford-New York 2010, s. 81-103 n. 
nie - Marian Cieślak — „nazwa »prawo karne« wiąże ten rodzaj prawa ściśle z pojęciem kary. Nasuwałoby się więc określenie, że prawo karne w znaczeniu najogólniejszym to przepisy prawne regulujące stosowanie kary"56. Dodać należy za Leszkiem Lernellem, że mówimy w tym przypadku wyłącznie o karze za przestępstwo, czyli karze kryminalnej ${ }^{57}$. Wyróżnia ją od innych rodzajów kar specyficznie osobisty i dolegliwy charakter, a zwłaszcza silny element społecznego potępienia. Tę cechę prawa karnego szeroko opisywał Joel Feinberg, definiując funkcję ekspresyjną kary kryminalnej ${ }^{58}$. Jak pisali następnie Andrew von Hirsch i Andrew Simester - prawo karne przemawia szczególnie umoralniającym głosem, jakiego brakuje w prawie cywilnym ${ }^{59}$. Istotą prawa karnego jest więc zagrożenie określonego zachowania karą kryminalną, a nie samo wymierzenie kary. W penologii zwracał już na to uwagę Anzelm Feuerbach ${ }^{60}$. Z całą pewnością dalecy jeszcze jesteśmy od osiągnięcia tego stanu rozwoju społecznego, o którym sto lat temu pisał Wacław Makowski: „Był czas, gdy oba pojęcia [przestępstwa i kary — przyp. J.U.M, J.K.] jeszcze się nie wykształciły, i przyjdzie taki, gdy znikną z umysłowości i życia społecznego - choć konflikty interesów dziś określane tymi pojęciami zapewne pozostaną"61.

Współcześnie więc ciągle istotną — wręcz coraz większą - rolę odgrywa w życiu społecznym prawo karne, mimo że jednocześnie możliwe jest coraz więcej — zarówno odstąpienie od wymierzenia kary, jak i właśnie alternatywne reagowanie na czyn zabroniony pod samą groźbą kary (kryminalnej).

Pomimo krytyki ze względów aksjologicznych (niemoralność) i prakseologicznych (ograniczona skuteczność), kara kryminalna przetrwała we wszystkich nowoczesnych społeczeństwach. Co więcej — także z perspektywy praw człowieka bezkarność w przypadku poważnych naruszeń praw człowieka, zarówno w skali makro (na przykład ludobójstwo, zbrodnie wojenne), jak i mikro (przemoc domowa), postrzegana jest jako poważne zagrożenie cywilizacyjne. Zjawisko, które określa się w literaturze tragicznością kary (kryminalnej), jest zatem widoczne. Tragiczność kary polega właśnie na tym, że wydaje się konieczna, choć nie jest

56 M. Cieślak, Polskie prawo karne. Zarys systemowego ujęcia, Warszawa 1994, s. 12.

57 L. Lernell, op. cit., s. 11.

58 J. Feinberg, Funkcja ekspresyjna prawa karnego, przeł. W. Mleczko, „Ius et Lex” 2006, nr 1.

59 A.P. Simester, A. von Hirsch, op. cit., s. 4. W naszej literaturze na rolę potępienia w określeniu kary kryminalnej szczególnie dobitnie wskazywał wcześniej niż wskazani autorzy z anglosaskiego kręgu kulturowego Juliusz Makarewicz (Prawo karne. Wykład porównawczy, Warszawa-Lwów 1924, s. V).

${ }^{60}$ Określa się to podejście do prawa karnego jako psychologiczną teorię przymusu. Teoria ta nie przyjęła się powszechniej w klasyfikacji teorii kary, natomiast myśl ta „ojca nauki prawa karnego", jak określa Feuerbacha z pewną przesadą między innymi Lernell, zawiera wiele myśli inspirujących analizy kary i prawa karnego. Por. idem, op. cit., s. 112-118.

61 W. Makowski, Podstawy filozofii prawa karnego, t. 1, Warszawa 1917, s. 6. 
zbyt efektywna i budzi zasadnicze obiekcje moralne. To właśnie ideały moralno-sprawiedliwościowe są często przywoływane w dyskusji społecznej w celu jej racjonalizacji ${ }^{62}$.

Ważnym ratio legis kary kryminalnej jako metody walki z przestępczością jest poczucie, że może nie tylko ograniczać przestępczość, lecz także dać jasną miarę uzasadnionej reakcji ujemnej na zarzucany czyn. Daje więc odpowiednio poczucie bezpieczeństwa, ładu i sprawiedliwości w społeczeństwie, którego ustrojową podstawą jest ochrona godności (każdego) człowieka.

Racją kary nie jest więc wcale w pierwszym rzędzie sama skuteczność, lecz właśnie sprawiedliwość, która, rzecz jasna, bez skuteczności także nie mogłaby zostać wymierzona. Gdyby główną racją kary była skuteczność w zwalczaniu przestępczości, to już dawno - jak to argumentował Foucault ${ }^{63}$ — porzucilibyśmy posługiwanie się karami - i to nie tylko karą więzienia, lecz wszelkimi formami kary kryminalnej. Zamiast prawa karnego rozwinęłoby się odpowiednio prawo do bezpieczeństwa, oparte na analizie ryzyka oraz wycenie szkód i odpowiednim stosowaniu środków zabezpieczających oraz kompensacyjnych. Kara kryminalna wymierzana $\mathrm{w}$ ten sposób, że próbuje się jakoś określić pewną adekwatność między tym, w jaki sposób zachował się sprawca a zakresem spotykających go z tego powodu negatywnych konsekwencji, nie miałaby z tej perspektywy żadnego racjonalnego uzasadnienia.

W nawiązaniu do rozważań na ten temat L.A Harta można zauważyć, że ze względu na skuteczność prawa karnego najsurowsze sankcje powinniśmy wymierzać za stosunkowo powszechne drobne przestępstwa - na przykład podatkowe czy wykroczenia drogowe. Właśnie w ich przypadku surowa i konsekwentnie egzekwowana kara mogłaby skutecznie odstraszyć potencjalnych sprawców. Natomiast większość zabójstw mogłoby się spotkać z relatywnie bardziej pobłażliwym wymiarem kary, bo wpływ surowości kary na potencjalnych sprawców zabójstw w przyszłości jest dużo bardziej problematyczny. Jeśli więc nie rozważamy orzekania kary wieloletniego więzienia za nieprawidłowe parkowanie czy drobne oszustwa podatkowe, surowszej niż kary orzekane za zabójstwo, to - jak wskazuje rozumowanie Harta - wynika to z innych względów niż argumentacja o nieskuteczności takiego ukształtowania wymiaru kary. Jak można zauważyć w nawiązaniu do uwag Harta — nie rozważamy takiej hierarchii kar przede wszystkim dlatego, że surowsze karanie za złe parkowanie czy niepłacenie podatków niż za zabójstwo raziłoby nas swoją niesprawiedliwością ${ }^{64}$.

62 J. Utrat-Milecki, Podstawy penologii..., s. 253.

63 Por. M. Foucault, Nadzorować i karać. Narodziny więzienia, przeł. T. Komendant, Warszawa 1998, s. 221-303.

${ }^{64}$ H.L.A. Hart, op. cit., s. 165-166; por. też omówienie J. Utrat-Milecki, Podstawy penologii..., s. 247-249 n. 
Zgodnie ze wskazanym rozumowaniem można przyjąć, że stosujemy powszechnie prawo karne rozumiane dosłownie jako posługiwanie się przede wszystkim karami stosowanymi w nawiązaniu do zasad odpowiedzialności karnej nie dlatego, że jest to najbardziej skuteczna metoda zwalczania przestępczości. Posługujemy się nim dlatego, że represja oparta na zasadach odpowiedzialności karnej i stosowaniu kary za zawiniony czyn może być względnie sprawiedliwa. Dodajmy, że przecież także dla gwarantowania sprawiedliwości tworzymy typy przestępstw i staramy się ściśle określić ich znamiona, nie zadowalając się ogólnikową klauzulą o surowym karaniu zachowań szkodliwych społecznie. Największą niesprawiedliwością jest karanie niewinnych, kolejną jest bezkarność winnych, lecz także kary trywialne i zbyt surowe naruszają poczucie sprawiedliwości, które współcześnie w prawie karnym wiąże się zawsze z prawami i wolnościami człowieka. Nie zmienia to faktu, że tak jak w przypadku zabójstwa czy nawet nieumyślnego spowodowania śmierci kara sprawiedliwa jest też w jakimś sensie po prostu konieczna po to, aby reakcja na dewiację była skuteczna. Jej skuteczność wynika raczej z potwierdzania pewnego ładu aksjologicznego niż prostej potrzeby zapobiegania podobnym przestępstwom w przyszłości. Jak wskazaliśmy wcześniej — sprawiedliwość do pewnego stopnia jedynie wtórnie analitycznie może być oddzielona od samej skuteczności.

Kara de facto legalnie ogranicza wolność i prawa człowieka, przede wszystkim poprzez różnego rodzaje deprywacje, w tym w szczególności różne formy pozbawienia wolności lub majątku, lecz czasami także nakazy (w szczególności pracy), a to musi być nie tylko skuteczne w zapobieganiu przestępczości, lecz również sprawiedliwe, przy czym gdy jest nieskuteczne, to też zapewne trudno mówić o sprawiedliwości ${ }^{65}$, albowiem w takim przypadku można by mówić o naruszeniu szerzej rozumianej zasady sprawiedliwości, obowiązku władzy gwarantowania wszystkim członkom społeczeństwa odpowiedniej ochrony prawnej przed bezprawnym i szkodliwym społecznie naruszaniem ich dóbr prawnych. Państwo ma prawo karania, lecz także odpowiednio — i współcześnie znajduje to też swój wyraz w prawie pozytywnym - ma obowiązek podejmować skuteczne działania w celu ochrony praw i wolności. Zaniechanie tego obowiązku lub też jego nieskuteczna realizacja ze względu na nieadekwatność rozwiązań prawnych i ich realizacji także może prowadzić do bardzo rażącej niesprawiedliwości wynikającej $\mathrm{z}$ bezkarności. Problem ten był dogłębniej analizowany w ostatnich latach przy przyjmowaniu rozwiązań prawnych związanych z prawnokarną ochroną przed przemocą domową. Za naruszenie praw człowieka uznaje się czasami niedostatecznie skuteczne ściganie i pobłażliwe karanie sprawców przemocy domowej czy brak kryminalizacji niektórych zachowań przemocowych ${ }^{66}$.

${ }^{65}$ L. Lernell, op. cit., s. 20-25 n.

${ }^{66}$ Kwestię tę bardziej omawia Sylwia Spurek we wstępie do opracowania: Ustawa o przeciwdziałaniu przemocy w rodzinie. Praktyczny komentarz, Warszawa 2011. 
Idąc dalej tropem refleksji na temat prawa maksymalnie zabezpieczającego przed przestępczością, stosowanego w miejsce prawa karnego, należałoby rozważyć, jaki w ogóle jest sens czekać, aż niebezpieczny sprawca choćby spróbuje po raz pierwszy zaatakować? Jakim prawem czekamy, wystawiając potencjalne, niewinne ofiary na ryzyko ataku? Jak wskazuje w szczególności kryminologiczna literatura amerykańska — także współcześnie podnoszą się głosy wprost wzywające do porzucenia koncepcji kary kryminalnej, w szczególności wobec sprawców przestępstw z użyciem przemocy i przejścia wobec nich na stosowanie środków zabezpieczających. Postulat ten współcześnie dotyczy też odejścia od oparcia stosowania represji karnej w odniesieniu do sprawców przestępstw z użyciem przemocy na zasadzie nullum crimen. Postuluje się zastąpienie jej zasadą powszechnego screening $u$ obywateli w celu wykrycia ewentualnej ponadnormatywnej skłonności do stosowania przemocy czy potępianych zachowań seksualnych i na tej podstawie trwałego izolowania takiej kategorii osób ${ }^{67}$. Realizacja tego postulatu musiałaby prowadzić do rewizji współczesnej koncepcji ochrony praw człowieka, która wyraźnie odwołuje się, jeśli chodzi o zasady stosowania represji karnej, do koncepcji kary kryminalnej, a więc odpowiedzialności za zawiniony czyn.

Z perspektywy praw człowieka kara kryminalna jest elementem ochrony praw podstawowych jednostki przed arbitralną ingerencją ze strony organów władzy działających w imieniu społeczeństwa. Na ten aspekt dyskusji penologicznej zwracał uwagę czołowy dwudziestowieczny prawnik anglosaskiego kręgu kulturowego - L.A. Hart. Pisał, że odejście od klasycznych zasad odpowiedzialności karnej, związanych — jak wskazał Lernell — integralnie z koncepcją kary kryminalnej jest nie tylko zmianą sposobu zwalczania przestępczości, lecz przede wszystkim fundamentalną zmianą o charakterze cywilizacyjnym oraz ustrojowym i dlatego wymaga dużej rozwagi ${ }^{68}$. Zmienia zasadniczo zasady ważenia interesów ogółu i interesu jednostki, której realny wpływ na to, czy zostaną wobec niej zastosowane określone środki zabezpieczające, w tym polegające na pozbawieniu jej wolności, może zostać istotnie obniżony. Pomysły tego rodzaju totalnej kontroli obywateli rozważał w swoim pismach z 1819 r. Ksawery Potocki — jeden z pionierów polskiej myśli penologicznej i penitencjarnej. Komentując projekt więzienia panoptycznego Jeremy'ego Benthama, stwierdzał mianowicie, że totalna kontrola nie tylko pozbawia człowieka zdolności do czynienia zła, lecz

67 Postulaty tego rodzaju w odniesieniu do sprawców przestępstw z użyciem przemocy zawiera praca amerykańskiego kryminologa Adriana Raine, The Anatomy of Violence: The Biological Roots of Crime, New York 2013, s. 303 n.

68 Por. H.L.A. Hart, op. cit.; omówienie tej kwestii zob. J. Utrat-Milecki, Podstawy penologii..., s. 243-247. 
w praktyce prowadzi do utraty zdolności do tego, żeby zła chcieć ${ }^{9}$. Społeczeństwo, w którym prawo karne zostałoby zastąpione prawem represyjnym opartym przede wszystkim na wyprzedzającej wycenie przyszłego ryzyka ze strony każdej jednostki - wycenie uzupełnionej o reguły kompensacji ewentualnie już wyrządzonych szkód - tworzyłoby zupełne inną cywilizację niż współczesna cywilizacja zachodnia. Społeczeństwa i jednostki muszą, zdaniem Harta, rozważyć, czy pragną w przyszłości żyć w grupie społecznej, w której jednostka zostanie całkowicie ubezwłasnowolniona.

Wydaje się, że dziś, mimo rozwoju prewencji sytuacyjnej w kryminologii i renesansu idei postpenalnych środków zabezpieczających, ciągle dominuje przekonanie o fundamentalnym znaczeniu idei wolności dla człowieka, w tym w szczególności wprost swobody poruszania się. Wolność ta analizowana jest jako fundament współczesnych koncepcji praw człowieka. Ten stan rzeczy implikuje ciągłe odwoływanie się do koncepcji prawa karnego czynu i zasady proporcjonalności (różnie dookreślanej) reakcji dolegliwej na ten czyn do jego szkodliwości społecznej i stopnia zawinienia ${ }^{70}$. Wskazują na to także najnowsze dokumenty prawnomiędzynarodowe, w tym Karta Praw Unii Europejskiej ${ }^{71}$ i, oczywiście, Konstytucja Rzeczypospolitej Polskiej. Nie ulega więc wątpliwości, że kara kryminalna pozostaje jednym z istotnych, można powiedzieć — konstytutywnych elementów prawa karnego, koniecznym dla realizacji jego funkcji sprawiedliwościowej. W literaturze anglosaskiej, jak to trafnie przypomina Alan Brudner, koncepcje kary kryminalnej opracowuje się właśnie po to, żeby jasno określić granice, w jakich państwo w imieniu różnie określanych racji może dokonywać drastycznych ingerencji w życie jednostek. Bez tych racji ingerencje te byłyby czasami wręcz poważnymi przestępstwami ${ }^{72}$. W końcu niczym innym niż przestępstwem jest samo pozbawianie człowieka wolności ${ }^{73}$, jeśli nie jest bardzo jasno uzasadnione prawnie, w szczególności jako kara pozbawienia wolności właśnie. W nawiązaniu do myśli między innymi A. von Hirscha można powiedzieć, że kwestia ta dotyczy ustalenia odpowiedniego przelicznika dolegliwości związanej z czynem

69 K. Potocki, Uwagi do projektu Ogólnego i szczególnego ulepszenia Administracji i stanu więzień publicznych, Warszawa, 6 marca 1819 r. (nie zaznaczono wydawcy), s. 7.

70 Warto w każdym razie wskazać, że choć szkodliwość społeczna czynu odnosi się do przeszłości, to obejmując też w sensie normatywnym elementy strony podmiotowej przestępstwa odpowiednio może stanowić istotny element prognozy kryminologicznej zachowania na przyszłość (por. art. $115 \S 2$ k.k.).

71 „Kary nie mogą być nieproporcjonalnie surowe w stosunku do czynu zabronionego pod groźbą kary", art. 49 pkt 3 Karty praw podstawowych Unii Europejskiej.

72 A. Brudner, Punishment and Freedom. A Liberal Theory of Penal Justice, Oxford-New York 2009, s. 1.

73 Por. k.k.: ,art. 189 par. 1: Kto pozbawia człowieka wolności, podlega karze od 3 miesięcy do 5 lat. Par 2. Jeżeli pozbawienie wolności trwało dłużej niż 7 dni, sprawca podlega karze pozbawienia wolności od roku do lat 10 ”. 
na dolegliwość związaną z karą, dodajmy — dolegliwości takiej, która jest jednocześnie dopuszczalna i bezwzględnie konieczna ${ }^{74}$. Jaki to będzie przelicznik, zależy w dużym stopniu od przyjętych rozwiązań prawnych, tradycji orzeczniczej, a także dominujących w doktrynie koncepcji penologicznych. Natomiast samo pytanie o ten przelicznik jest ważne niezależnie od możliwości udzielenia na nie różnych, w istotnych szczegółach, odpowiedzi w poszczególnych jurysdykcjach, albowiem bezsporne jest w penologii, że nie ma ontologicznej jedności między bytem przestępstwa i bytem kary, a ewentualne dążenia do jej ustanowienia należą do odległej historii kary (klasyczny talion czy kary odzwierciedlające) ${ }^{75}$.

Swego rodzaju dyspensa, jakiej państwo udziela na podejmowanie ingerencji penalnej, wymaga bardzo jasnego usprawiedliwienia oraz określenia jej granic tak, aby nie uderzyć w podstawy współczesnego rozwoju cywilizacyjnego i ustroju demokratycznego, za jakie wypada uznać poszanowanie praw każdego człowieka. Niewątpliwie ważenie różnych racji może prowadzić do zmian polityki kryminalnej i dotyczy to zarówno zmiany w rozumieniu wolności i bezpieczeństwa, jak i zmian wynikających z nowych sposobów technicznych walki z przestępczością. Jednak rozwój cywilizacyjny nie unieważnił samego pytania o legitymizm działań państwa ograniczających wolność jednostce, a więc też pytania o sprawiedliwość, o to, jakim prawem ogranicza się danej jednostce w określonym wymiarze jej prawa. Dlatego wydaje się, że dyskurs na temat sprawiedliwości w prawie karnym pozostaje ciągle równoważny dyskursowi na temat samej skuteczności stosowanych środków i wskazana współzależność obu analitycznie wyróżnianych aspektów funkcjonalnych prawa karnego pozostaje ciągle aktualna.

Możemy przyjąć pewnego dnia, że wszyscy powinniśmy być ex lege ubezwłasnowolnieni, a uprawnione organy mają jedynie nas wszystkich badać, aby ocenić stopień, w jakim możemy stwarzać ryzyko dla siebie i innych na przyszłość, i na tej podstawie określać zakres naszego zniewolenia. Być może taka procedura powinna dotyczyć tylko wybranych przestępstw z użyciem przemocy, jak to sugeruje powoływany wcześniej Adrian Raine ${ }^{76}$. Byłby to już jednak zupełnie inny projekt cywilizacyjny niż ten wyznaczony współczesnymi dokumentami odnośnie do praw człowieka. Last but not least, gdyby w tym nowym projekcie okazało się, że wobec tej procedury bezpieczeństwa niektórzy są faworyzowani, a inni dyskryminowani, oraz że nie podlegają jej tak samo kontrolerzy co kontrolowani, to ewentualny bunt wobec tego projektu totalitarnego na sztandarze obok idei wolności zapewne miałby ideę sprawiedliwości.

VI. Jakkolwiek analizy teoretyczne na temat sprawiedliwości, rozwijane na tle doświadczeń społeczeństw funkcjonujących w różnych systemach prawnopo-

74 Por. A. von Hirsch, Seriousness, severity and the Living standard.

75 Por. J. Utrat-Milecki, Podstawy penologii..., s. 130; L. Lernell, op. cit., s. 57- 70.

76 A. Raine, op. cit., s. 303 n. 
litycznych, pozwalają na uzmysłowienie sobie wagi tej wartości, to jej znaczenie jest jeszcze bardziej unaocznione, gdy mamy do czynienia z uwarunkowaniami jej wymierzania w konkretnych sytuacjach. Widać wówczas, jak wielkim problemem jest potraktowanie badanych „faktów jak rzeczy”, gdy w grę wchodzi wysoko emocjonalna obrona wartości, które są w odmiennym stopniu odczuwane i uznawane nie tylko przez różne odłamy społeczeństwa, lecz także poszczególnych ludzi.

Do osiągnięcia pewnego poziomu „bezosobowej racji faktów” w decyzjach zapadających w strukturach wymiaru sprawiedliwości wprowadza się zasady metodyki pracy funkcjonariuszy, które nie tylko wymuszają obiektywizowanie procesu weryfikacji materiałów dowodowych, lecz przede wszystkim ustalają ścisłe reguły (procedury) stosowania prawa ${ }^{77}$. Powstrzymuje się tym sposobem najbardziej oczywiste błędy i nadużycia oraz ogranicza wpływ uprzedzeń i prywatnych przekonań światopoglądowych sądzących. Wdrożenie metodyki pracy prowadzi do ułatwienia postępowania, w tym także poprzez wprowadzenie dyscyplinującego harmonogramu podejmowanych czynności. Zabezpieczenia systemowe w postaci metodycznie regulowanej procedury wyrażają pośrednio sceptycyzm wobec upowszechnienia cnoty sprawiedliwości jako osobistego przymiotu osób sądzących. Wymaganie, by pewne zawody były wykonywane przez osoby cechujące się nie tylko sprawnością w stosowaniu formalnych instrumentów wymierzania sprawiedliwości, lecz dodaną do niej pewną pozytywną właściwością umysłu i charakteru wynika z doświadczenia wskazującego na tendencje do stronniczości w postępowaniu większości ludzi. Sprzyjanie „swoim”, dbanie o własny interes kosztem innych, mierzenie siebie odmienną miarą niż innych — bez poczucia winy i wyrzutów sumienia - dzieje się bezwiednie ${ }^{78}$. Nikt na ogół nie roztrząsa wyrządzonej przez siebie niesprawiedliwości, gdy nie jest do tego nakłoniony. Niesprawiedliwość doznana postrzegana jest w zupełnie innej optyce.

Rozpatrywane przez C. Perelmana kryterium sprawiedliwości, najbliższe potrzebom wymiaru sprawiedliwości, wyraża się w sformułowaniu „każdemu według tego, co przyznaje mu prawo". Warunkiem jego realizacji jest obiektywizm sędziego wyrażający się rozpatrywaniem powierzonych mu spraw w zgodzie z obowiązującym prawem, zasadami jego stosowania zgodnie z orzecznictwem, a nie własną wizją porządku prawnego. Jednak założenie o możliwości niwelowania preferencji aksjologicznych funkcjonariuszy wymiaru sprawiedliwości jest w pewnej mierze idealistyczne, stanowi w istocie punkt odniesienia i kontroli dla praktyki, a nie przekonanie o bezwyjątkowej możliwości spełnienia. Postulowa-

77 P. Hofmański, S. Zabłocki, Elementy metodyki pracy sędziego w sprawach karnych, Warszawa 2011.

78 Potwierdzają to liczne badania psychologiczne pokazujące fałszowanie danych na korzyść siebie lub osób z własnego kręgu. Szczególnie wyraźnie pokazują to badania eksperymentalne. O zjawisku tym wspominała też Maria Ossowska (op. cit., s. 153-156). 
na jako zasada nieskazitelność sędziego w sensie nadanym przez Perelmana, jako stosowanie tych samych praw w tych samych sytuacjach (in paribus causis paria jura), jest w rzeczywistych sytuacjach stanem wyprowadzonym nie tylko z ustawowego porządku prawnego, lecz także z osobistego, wewnętrznego poczucia sprawiedliwości sądzącego. Każdy z tych porządków jest oparty na określonej skali wartości, która nie jest stała ani pod względem selekcji samych wartości, ani przypisanego im znaczenia. W wielu przypadkach sfera wyboru i siły akcentowania wybranych wartości leżących u podstaw rozstrzygnięcia, jaką dysponuje sądzący, jest wystarczająco duża, by mógł on, nawet bez naginania prawa, dać wyraz uznawanej przez siebie hierarchii norm.

Zasadą wymiaru kary z art. 53 k.k. jest to, że sąd wymierza karę według swojego uznania. Uznanie sędziego, choć ograniczone przepisami ustawy, w tym koniecznością uwzględnienia w uzasadnieniu innych zasad i dyrektyw wymiaru kary, daje sędziemu w praktyce szczególnie istotny wpływ na kształt kary w realiach społecznych. Znajduje to także empiryczne potwierdzenie w praktyce, kiedy w poszczególnych okręgach sądowych występuje ogromna różnica przy podobnej skali przestępczości, jeśli chodzi o wymiar kar, zarówno rodzaj, jak również w zauważalnym stopniu - ich wymiar ilościowy. Nie są to więc różnice po stronie sprawcy i czynu, lecz po stronie sądu — poszczególnych sędziów i całej kultury lokalnej okręgu sądowego. W rękach sędziego znajduje się szczególnie interpretacja pojęć mglistych oraz nowych i nieprecyzyjnych wyrażeń prawnych. Znane są przypadki pomijania w praktyce sądowej sugerowanych interpretacji prawa pod hasłem, że lokalnie „się nie przyjęły”, gdyż nie pasują do kontekstu kulturowego danej społeczności. Próby ujednolicenia praktyk w zakresie wymiaru kary są obok innych racji wiązane także z przekonaniem, że stan takiego zróżnicowania po przekroczeniu pewnych granic może rażąco kłócić się ze społecznym poczuciem sprawiedliwości, rodząc pytanie, o czyją sprawiedliwość chodzi.

Prawość (equité), występująca jako pojęcie towarzyszące sprawiedliwości, nie została u Ch. Perelmana zdefiniowana jako osobista cnota, właściwość charakteru człowieka, lecz jako forma etycznej interwencji normatywnej, stającej się „podporą sprawiedliwości"79. Prawe rozwiązanie może wprowadzić każda osoba, która jest zobowiązana do podjęcia decyzji dotyczących życia publicznego w jakichś szczególnych warunkach, które sprawiają, że stosowanie dotychczasowych, skodyfikowanych zasad sprawiedliwości byłoby wobec oddziaływania czynników zakłócających w powszechnym odczuciu niesprawiedliwe ${ }^{80}$. Oparcie decyzji na prawości, skorygowanie nią zasad sprawiedliwości jest odwołaniem się do moralności. Prawe działanie jest poprawką naniesioną z przyczyn etycznych na sformalizowane zasady wymiaru sprawiedliwości. W tym kontekście trzeba podkreślić

79 C. Perelman, op. cit., s. 70.

${ }^{80}$ Na przykład zarządzenie wypłaty odszkodowania według określonych stawek nie biorących pod uwagę wysokiej inflacji. 
znaczenie stwierdzenia Perelmana, że „być sprawiedliwym, to nie znaczy poprawnie stosować byle jakie prawidło" ${ }^{\prime 1}$. W Polsce ta sprawa jest aktualna i niezwykle bulwersująca na tle dokonań reprywatyzacyjnych, które stały się przedmiotem krytyki po 27 latach od ich rozpoczęcia. Wobec uchybień sędziów, którzy w tym zakresie podejmowali decyzje wąsko w granicach przepisów, Andrzej Zoll postawił pytanie: „Gdzie tu racjonalny wyrok, skoro sędzia myśli o przepisach, a nie o sprawiedliwości?" 82 .

Sama natura życia społecznego sprawia, że decyzje sądzących odnoszą się nie tylko do przedmiotowych spraw, lecz wyrażają także zaktualizowaną ocenę możliwości stosowania zasad sprawiedliwości prawnej. Każdy sędzia w swojej praktyce ma liczne doświadczenia z ustalaniem porządku wartości, które w konkretnych przypadkach bierze pod uwagę w swoich decyzjach. Nie we wszystkich okolicznościach może się odwołać do powszechnej zgody w sprawie uwzględnionych w ocenie danego zdarzenia norm i wartości. Musi sam znaleźć drogę do właściwego ujęcia problemu w kontekście swoich i społecznych wartości nie tylko uznawanych, lecz też odczuwanych ${ }^{83}$. W tym procesie następuje też wyłączenie czynników bezzasadnie faworyzujących czy dyskryminujących osoby należące do określonych kategorii, albowiem to, co faworyzuje bądź dyskryminuje w wymiarze sprawiedliwości, powinno być uzasadnione odwołaniem się do wartości hierarchizujących dobro jakichś jednostek lub grup. Jednak już samo wskazanie parametrów wyróżnienia pewnych jednostek lub grup jest aktem informującym o możliwości oddziaływania tych czynników na sprawiedliwość werdyktu sądu.

Analityczna skrupulatność postępowania sądowego wymusza wskazanie niektórych mniej oczywistych, choć ogólniejszych treści aksjonormatywnych stojących za każdą decyzją. Ten problem unaocznił Eugène Dupréel, kiedy opisał, jak egalitarna formuła sprawiedliwości $\mathrm{w}$ istocie wspiera ideał poszanowania czci i godności ludzkiej, a formuła „każdemu według potrzeb” odpowiada idei ochrony ludzi przed cierpieniem, stwarzania im korzystnych warunków życia, zaś formuła doceniania zasług (,każdemu według zasług”), zawarta w regule sprawiedliwości, jest uznaniem społecznej wartości wyjątkowych czynów, talentów i zdolności ${ }^{84}$. Chaim Perelman, powołując się na przykłady podane przez E. Dupréela, potwierdzał, że „każdy system sprawiedliwości zależy od wartości założonych przez jego zasady. Jednakże sprawiedliwość ma własną wartość niezależnie od wartości, na których się opiera: wynika ona $\mathrm{z}$ faktu, że stosowanie jej zadowala potrzebę

81 C. Perelman, op. cit., s. 76.

82 Nie święci wyroki lepią. Z Andrzejem Zollem rozmawia Agnieszka Kublik, „Gazeta Wyborcza" 3-4 września 2016, s. 16.

83 S. Ossowski, Konflikty niewspótmiernych skal wartości, [w:] idem, Dzieła, t. III. Z zagadnień psychologii spotecznej, Warszawa 1967.

84 Zob. C. Perelman, op. cit., s. 102-103. 
konsekwencji i prawidłowości" ${ }^{85}$. Główna wartość sprawiedliwości polega na jej mocy konsolidacyjnej wobec innych wartości systemu aksjonormatywnego. $Z$ tego względu obywatele mogą odwoływać się do niej jako wartości nadrzędnej i polegać na opartych na niej regulacjach zarówno wtedy, gdy chodzi o świadczoną na jej podstawie powinność pozytywną, jak i negatywną.

Dodać trzeba, że sprawiedliwość jako podstawę ustroju społecznego tworzy konstrukcja złożona z systemu aksjonormatywnego, formalnie ustalonych zasad sprawiedliwości oraz działań, które je w praktyce uwzględniają. Ten trójelementowy mechanizm powinien być spójny, aby powszechne odczucie sprawiedliwości wspierało trwanie tego układu. Nie oznacza to jednak, że kiedykolwiek społeczeństwo będzie doświadczać absolutnie doskonałego systemu sprawiedliwości i będzie wobec niego bezkrytyczne.

Odwołanie się we współczesnym opracowaniu do mocno zakorzenionych w ideach starożytnej myśli filozoficznej klasycznych prac na temat sprawiedliwości, tworzonych przede wszystkim w kręgu dwudziestowiecznych analityków, jak Eugène Dupréel, Chaim Perelman czy Maria Ossowska, zajmujących się normami moralnymi, ma uzasadnienie w ustaleniu przez nich ram badawczych tej podstawowej dla tego tematu dyscypliny — nauki o moralności. Z ich wnioskami konfrontuje się także współczesne analizy teoretyczne i w świetle ich uwag spogląda na programy badań empirycznych nad sprawiedliwością, prowadzonych w obszarze nauk prawnych i społeczno-filozoficznych. Na szczególną uwagę zasługują prace kręgu bliskich kontynuatorów tego nurtu nauki o moralności, mianowicie badaczy z warszawskiej szkoły filozoficzno-logicznej, analizujących w najogólniejszym zakresie problem źródeł oraz prawomocności wiedzy ${ }^{86}$. Ich uwagę przyciąga proces decyzyjny jako zagadnienie wewnętrznego dociekania naukowego uwarunkowanego szeregiem zamaskowanych wyborów. W świetle tych zainteresowań zrozumiałe jest włączenie do problematyki badawczej analogicznego zagadnienia podejmowania decyzji noszących cechę sprawiedliwości, którymi jest nasycona rzeczywistość wymiaru sprawiedliwości. Zwracają oni uwagę na rolę, jaką w procesie analizy zjawiska czy faktu (na przykład analizy przestępstwa) odgrywają nie tylko normy i zasady postępowania badawczego, lecz także oceny i preferencje badacza (sędziego), który stosuje określoną metodologię i wykazuje się twórczością w zakresie uporządkowania, akcentowania i interpretacji danych. Co najistotniejsze z punktu widzenia sprawiedliwości karnej — badacze ci wykazali, że w analizach prowadzonych w obszarze prawa należy brać pod uwagę, że bezpośrednie deklaracje ludzi, dotyczące zasad sprawiedliwości, gorzej odzwierciedlają ich stanowisko wobec sprawiedliwości niż — o ile są one możliwe do uzyskania - dane empiryczne wydobyte z analizy zgodności dokonanych przez

85 Ibidem, s. 104.

86 Do grona tych badaczy zalicza się między innymi Klemansa Szaniawskiego, Grzegorza Lissowskiego, Annę Wójtowicz. 
nich rzeczywistych ocen z ocenami normatywnymi. Przeprowadzone przez nich eksperymenty dowodzą, że ludzie kierują się w polu własnej działalności wieloczynnikową analizą rzeczywistości i reagują na nią w sposób skomplikowany. Potrafią podjąć - nie zawsze świadomi wszystkich elementów podłoża aksjologicznego - sprawiedliwe decyzje lub opisać niesprawiedliwość innych — nie tylko w świetle obowiązujących zasad, lecz także konsekwencji, jakie przynoszą różnym partnerom relacji społecznych.

Działalność tej szkoły naukowej pokazuje, że kultura badań polegająca na teoretyczno-metodologicznej integracji daje szansę porównaniom dokonywanym w różnych obszarach życia społecznego, zbliża dyscypliny i lokuje przedmioty ich badań w podobnych sytuacjach analitycznych. Konfrontacja wyników tych filozoficzno-logicznych badań i analiz, zespolona z teorią integralnokulturową wyjaśniającą zjawiska i procesy w obszarze wymiaru sprawiedliwości podnosi poziom wyjaśniania faktów — w szczególności tak złożonych, jak sprawiedliwa kara i karanie.

„Sędzia musi sądzić” niezależnie od tego, jak wiele ma wątpliwości w związku z definiowaniem pojęcia sprawiedliwości i ile zastrzeżeń budzą w nim zasady aktualnego prawa. Prawo obywatela do sądu, uznawane za prawo człowieka i zapisane w konstytucji, zobowiązuje sędziów do wykonywania czynności zawodowych bez względu na rodzaj i siłę krytycyzmu wobec warunków, w jakich podejmowane są czynności sądzenia. Jak jednoznacznie stwierdza Kodeks karny Napoleona - „Sędzia odmawiający wyrokowania, pod pozorem, że prawo milczy, że jest mgliste, albo niedostateczne, może być pociągniętym jako winny odmówienia sprawiedliwości”87. Właśnie ta sytuacja, gdy z jakichś powodów nie można się odwołać do jednoznacznych zasad prawa, pokazuje znaczenie osobistej prawości sędziego, który respektując doktrynalną intencję ustawodawcy, zrozumiałą dla społeczeństwa w świetle panujących norm moralnych i religijnych, uzupełnia swoją interpretacją nieobecne prawa lub je rozjaśnia. Posługując się prawem, sędzia daje wyraz swojej prawości.

Decyzje sędziego podejmowane w warunkach mglistości prawa nie mogą stanowić naruszenia obowiązującego prawa. Muszą zawsze respektować ducha ustanowionego prawa. Jego przestrzeganiu służy odwoływanie się w toku interpretacji nawet ogólnikowego i niejasnego prawa do zasad jego wykładni oraz reguł inferencyjnych, oraz uwzględnianie dorobku orzecznictwa, albowiem rozwiązania przyjmowane przez sędziego w konkretnych sytuacjach nie usuwają nadrzędnej roli prawodawcy.

VII. Zagadnienie uwarunkowań cywilizacyjnych funkcjonowania wymiaru sprawiedliwości karnej jest niezwykle złożone ${ }^{88}$. Poniżej rozpatrujemy kwestię

87 Kodeks karny Napoleona, art. 4.

$88 \mathrm{Na}$ temat integralnokulturowych badań podstaw cywilizacyjnych rozwoju prawa karnego w Polsce por. J. Utrat-Milecki, L'idéologie pénale et la fondation de la IIIe République polonaise 
wpływu na sędziowskie kształtowanie kary niektórych czynników wskazanych jako istotne w empirycznych badaniach prowadzonych w polu wymiaru sprawiedliwości metodami nauk społecznych. Kwestia sprawiedliwości występuje tu jako centralna i wiążąca, co pozwala na rozwinięcie wokół niej dalszych, mocniej uwiarygodnionych metaanaliz dotyczących jej promieniowania na inne parametry kary.

Jeden z ważniejszych dla sprawiedliwości temat relacji między ustawowym a sędziowskim wymiarem kary został po raz pierwszy w Polsce podjęty w formie empirycznego badania socjologiczno-prawnego przez zespół polskich badaczy z Uniwersytetu Wileńskiego na krótko przed drugą wojną światową. Bronisław Wróblewski i Witold Świda opracowali i zrealizowali badania na próbie 285 sędziów wszystkich szczebli, których zapytali o ich praktykę zawodową związaną z wymierzaniem kary. Badanie Wróblewskiego i Świdy było przeprowadzone w szczególnym momencie historycznym dla polskiego wymiaru sprawiedliwości. W 1932 r. wszedł w życie kodeks karny, który — jak stwierdził Bronisław Wróblewski - „Dając sędziemu wiele, wiele od niego wymaga" ${ }^{\text {" }}$. To, czego kodeks wymaga, to przede wszystkim ,wysokiego wykształcenia i spokojnej, pełnej rozwagi pracy" 90 .

Pomijając zastrzeżenia, jakie zawsze można podnosić wobec samych zasad sprawiedliwości leżących u podstaw doktryny wymiaru sprawiedliwości karnej dominującej w określonym momencie historii danego społeczeństwa, należy podkreślić, że w każdych systemowych uwarunkowaniach zakłada się, iż sędziowski wymiar kary będzie wymiarem sprawiedliwym pod względem miary i ewentualnie rodzaju kary. Ten warunek sprawiedliwości kary ma być wypełniony przez pracę sędziego. Jego rola rośnie, gdy upoważnienie, jakie otrzymuje sędzia z rąk ustawodawcy odnośnie do sądowego wymiaru kary, jest szerokie i nastawione przede wszystkim na prewencję indywidualną (jak w art. 54 k.k. z 1932 r.). W tym przypadku sprawiedliwość wyrażona wymiarem orzekanego środka, oparta na swobodnej, sędziowskiej ocenie, rozciąga się w szerokiej słabo oznaczonej przestrzeni. Do sędziego należy także niezwykle istotna sprawa umotywowania wyroku, to jest podania racjonalizacji wyboru miary i ewentualnie rodzaju kary lub zastosowania środka zabezpieczającego i przedstawienia tego stanowiska opinii publicznej, która może śledzić szczególnie interesujące ją przypadki, aby wyrobić sobie zdanie o ogólnym stanie panującej sprawiedliwości.

après 1989, [w:] La fondation dans les langues indo-européennes: linguistique et religion, red. M. Mazoyer, Paris 2014, s. 229-251; a w kontekście ogólnoeuropejskich procesów cywilizacyjnych: J. Utrat-Milecki, The effects of the civilizing proces on penal development in the European Union, [w:] EU Criminal Law and Policy. Values, Principles and Methods, red. Ch. Harding, J.B. Banach-Gutierrez, London-New York 2017, s. 21-36.

89 B. Wróblewski, Ustawowy a sędziowski wymiar kary (referat sprawozdawczy), Warszawa 1936, s. 19.

90 Ibidem. 
Hipoteza, że sędzia pomimo swego wykształcenia i sprawowanej nad jego działalnością kontroli systemu, kieruje się przede wszystkim swoim światopoglądem i własnym doświadczeniem życiowym oraz pewną tradycją stworzoną w bliskim środowisku zawodowym i porównawczym dostosowaniem do wyroków innych sędziów, wydała się Wróblewskiemu niepokojąca ${ }^{91}$. Oczekiwał on od sędziów niezależności ocen, głębokiego zrozumienia idei sprawiedliwości przekazanej w kodeksie i aktywnego rozwijania ducha kodeksu w polu sędziowskiego wymiaru kary. Leżąca w rękach sędziów indywidualizacja wymiaru kary pojmowana była przez niego jako postępowanie wszystkich sądzących według tych samych kryteriów w sytuacjach, w których grają rolę te same zmienne. Była to indywidualizacja z perspektywy właściwości sprawy i sprawcy, a nie sędziego. Ocena wpływu dodatkowych czynników na winę i karę powinna mieć charakter uporządkowany i zależeć od kryteriów obiektywnych, a nie światopoglądu czy emocji sędziego. Taka ocena powinna być weryfikowalna w tym sensie, że sędzia, wymierzając karę, może się powołać na obiektywne wyznaczniki jej miary i ewentualnie rodzaju (formy).

Powaga kary wynika z zabezpieczania nią sprawiedliwości, której najwyższą szkodę wyrządza skazanie niewinnego, bezkarność, lecz poważnie szkodzi też kara nieadekwatna. W społeczeństwach demokratycznych odrywanie się sędziów od doktryny — zarówno to świadome, kontestujące jej zasady, jak i to bezwiedne, wynikające z ignorancji, jest wyrządzaniem szkód sprawiedliwości. Są one odczuwane nie tylko na poziomie losu jednostki, lecz trwale dotykają spraw ustrojowych państwa oraz jego relacji z obywatelem.

W badaniu kwestionariuszowym Wróblewskiego i Świdy, które zawierało 20 punktów, 9 dotyczyło spraw bezpośrednio związanych z karą i karaniem. Autorzy ankiety starali się dowiedzieć od sędziów o branych przez nich pod uwagę celach karania, znaczeniu psychicznych i społecznych cech sprawcy oraz jego motywacji dla wymiaru kary oraz czy, i w jakim zakresie, sędziowie uwzględniają prewencję generalną przy wymiarze kary. Chcieli zbadać świadomość oddziaływania na nich samych grona sędziowskiego i autorytetów prawniczych oraz wpływ antycypowanej oceny instancji odwoławczej na wymiar kary. Badacze pytali także o stosowanie przez sędziego przekroczenia najwyższego ustawowego wymiaru kary (w przypadku recydywy) i o odczucia braku jakiegoś nieprzewidywanego przez kodeks środka karnego w obliczu szczególnego przestępstwa lub sprawcy. Pytali też o przypadki odczuwania przez sędziego potrzeby zejścia poniżej minimum kary oraz o decyzje uniewinnienia lub zawieszenia kary w przypadku braku możliwości zejścia poniżej minimum. Na pytania te można spojrzeć z perspektywy procesu wypracowywania przez sędziów sprawiedliwych wyroków. Nie chodzi przy tym o sprawiedliwość abstrakcyjną, lecz konkretną. Obydwaj autorzy

\footnotetext{
91 Ibidem.
} 
badania, a szczególnie Bronisław Wróblewski, byli ciekawi oddziaływania wielu zmiennych na sprawiedliwą karę i chcieli ich identyfikacji oraz opisu. Wyrażali zainteresowanie ustandaryzowaniem systemu karania w zakresie sędziowskiego wymiaru kary i uważali, że zróżnicowanie kar, wynikające z sędziowskiej oceny przypadku, powinno mieć zawsze te same podstawy i uzasadnienie. Wspólne podstawy indywidualizowania wymiaru kary (jej osobowego różnicowania) miały w ich odczuciu nie tylko czynić konkretną karę bardziej sprawiedliwą, lecz także tworzyć pozytywną opinię o rzetelności wymiaru sprawiedliwości, a więc o sprawiedliwym państwie. Obawiali się, że pozbawiona argumentów merytorycznych dowolność w zakresie podstaw indywidualizowania prowadzi do upowszechnienia interpretacji, iż kara jest pochodną kaprysu bądź charakteru sądzącego, wynikiem jego preferencji światopoglądowych i uprzedzeń albo oddziaływania nieformalnego środowiska regionalnego. Postrzegali to jako skandaliczne.

Pytania zawarte w kwestionariuszu Wróblewskiego i Świdy na temat tego, „jak sędzia stosuje wymiar w praktyce?”, zmierzały do zebrania wiedzy o linii orzeczniczej konkretnych sędziów, miały wyławiać faktyczne czynniki determinujące decyzje sędziego, lecz także wskazywać niedoskonałości kodeksu karnego. Był to zatem nie tylko test prawidłowości sędziowskiego wyrokowania, lecz również sprawdzian jakości narzędzia — kodeksu, jakim się posługiwali. Nie bez znaczenia był trzeci element kształtujący wymiar kary w postaci wadliwie działającego systemu penitencjarnego, który pośrednio wpływał na decyzje sędziów. Osłabiał ich tendencje do wyrokowania sformalizowanego, adekwatnego do winy, na rzecz orzekania, w którym brano pod uwagę zagrożenie głębszą demoralizacją skazanych w wyniku pobytu w dysfunkcyjnych zakładach karnych. Badacze stwierdzali, że „im słabiej stoi wykonywanie kar, tym większe znaczenie zyskuje sędziowski wymiar kary. Nie dla każdego sędziego jest obojętne, co się stanie z jego wyrokiem"92.

Ukształtowanie kary jako sprawiedliwej jest pochodną wielu czynników, w tym duże znaczenie odgrywa przygotowanie zawodowe sądzącego. Wróblewski miał bardzo krytyczny stosunek do efektów kształcenia sędziów w tym zakresie. Pisał:

sędzia, czy to podczas studiów uniwersyteckich, czy też w literaturze prawniczej spotykał się głównie — jeśli nie wyłącznie — z takimi zdaniami o karze, które nie były sądami wyprowadzonymi przy użyciu aparatu naukowego. Jedne zdania należały do grupy wniosków filozoficznych o istocie kary, drugie — były to wypowiedzi dogmatyczne, związane z tradycjami języka prawniczego, trzecie wreszcie — stanowiły poglądy zaczerpnięte z polityki karnej, uprawianej u nas w sposób domorosły. Jeśli nawet sędzia spotykał się z naukowymi sądami o karze, to $\mathrm{i}$ te łącznie $\mathrm{z}$ innymi kryminologicznymi wiadomościami zostały szybko

92 B. Wróblewski, W. Świda, op. cit., s. 13. 
puszczone w niepamięć: potoczne życie i rzeczywistość nie odpowiadająca książkowej zrobiły swoje ${ }^{93}$.

Pragnienie, aby wyposażyć sędziów w zintegrowaną wiedzę penologiczną wiążącą przede wszystkim wątki psychologiczne, socjologiczne i kryminologiczne podparte było przekonaniem, że wiedza naukowa jest w stanie w sposób ukierunkowany wzbogacić zwykły zdrowy rozsądek i osobiste doświadczenie sędziego w procesie oceny materiału sądowego, na którym opiera się wymiar kary. Pogląd o konieczności wzmocnienia penologiczno-kryminologicznego wykształcenia przyszłych sędziów wyrażał już wcześniej w latach 20. czołowy polski karnista, konstytucjonalista oraz minister sprawiedliwości i senator sanacyjny Wacław Makowski ${ }^{94}$.

Swoją analizą Wróblewski, podobnie jak wcześniej W. Makowski, a także choć już przede wszystkim odnośnie do sprawy wykonania kary — Leon Rabinowicz i Jerzy Śliwowski ${ }^{95}$, pokazuje konieczność wyjęcia tematów kary i karania z pola naukowej wyłącznej odpowiedzialności nauk prawnych i zaangażowania do ich analizy szeroko pojętych nauk społecznych. Dużo bogatsza pod względem dyscyplinarnym wiedza integralnokulturowa o karze byłaby tym, co stymulowałoby zmiany i pomniejszało wpływ niekorzystnych czynników personalnych (emocjonalnych, charakterologicznych, biograficznych, światopoglądowych) w działaniach struktur wymiaru sprawiedliwości i je obiektywizowało. Między innymi — do czego Wróblewski przywiązywał ogromną wagę - stwarzałoby to warunki do tego, że rzetelniej dokonywana byłaby selekcja przesłanek ustalających relacje między winą sprawcy a karą oraz ustalana proporcja celów, jakie kara ma w danym przypadku osiągnąć.

Jeden z rodzajów racjonalizacji kary, wymieniony w typologii B. Wróblewskiego, nosi nazwę racjonalizacji sprawiedliwościowej. Jest ona zaliczana przez niego do grupy racjonalizacji metafizycznych, akcentujących sprawiedliwościową istotę kary jako proporcjonalnej odpowiedzi na zawiniony czyn ${ }^{96}$. Wróblewski, będąc zwolennikiem sprawiedliwej odpłaty i sprawiedliwego odwetu, uznaje, że „drogowskazem ustawodawcy karnego"97 musi być poczucie sprawiedliwości. W przeprowadzonej przez niego orientacyjnej typologii racjonalizacji kary do-

93 Ibidem, s. 37-38.

94 Uczony ten postulował wprowadzenie od III roku studiów prawniczych dwuletniego studium kryminalistycznego obejmującego wykłady monograficzne między innymi z filozofii prawa karnego, psychologii, psychopatologii, etiologii i polityki kryminalnej, więziennictwa, medycyny sądowej. (W. Makowski, Rozważania prawnicze z dziedziny prawa publicznego; z dziedziny prawa karnego - mowy, Warszawa 1928, s. 304, 308-309).

95 L. Rabinowicz, Podstawy nauki o więziennictwie, Warszawa 1933, s. 341 n.; J. Śliwowski, Nowe prady w sądownictwie karnym, „Głos Sądownictwa” 1933, nr 10.

96 B. Wróblewski, Penologia. Socjologia kar, t. I, Wilno 1926, s. 184-223.

97 B. Wróblewski, W. Świda, op. cit., s. 92. 
minującej w artykułach kodeksu karnego z 1932 r. wynika, że rzeczywiście taka racjonalizacja sprawiedliwościowa, obecna w 21 artykułach k.k., była brana pod uwagę przez ustawodawcę najczęściej. Po niej dopiero następowała tak zwana racjonalizacja obronna (15), szczególniepowściągowa (14), walkowo-poprawcza (13), wychowawcza (6), ogólniepowściągowa (5) ${ }^{98}$. Kodeks karny z 1932 r. opierał zatem w dużej mierze ustawowy wymiar kary za przestępstwa zasadnicze na sprawiedliwościowej racjonalizacji kar, rozumianej jako odwet za zawiniony czyn, co oznaczało reakcję wymiaru sprawiedliwości, zachowującą pewną równowagę między wartością zaatakowanego dobra a dolegliwością kary.

Jednakże analizując dokładnie kodeks karny z 1932 r. pod względem racjonalizacji przyjmowanej dla kar, Wróblewski stwierdzał, że „dana instytucja lub norma mogą być teoretycznie związane z kilkoma różnymi racjonalizacjami ujemnych reakcji" "99. Choć zatem racjonalizacja sprawiedliwościowa (retrybutywna, imperatywna) była wiodąca z jej akcentowaniem odwetu i sprawiedliwej odpłaty za zawiniony czyn, to ważne było także znaczenie innych typów racjonalizacji kary. Wynikało to z faktu, że ustawodawca musiał brać pod uwagę z jednej strony wymierzenie odpłaty sprawiedliwej w sensie proporcjonalności kary do winy i czynu, a z drugiej — co najmniej równie ważnej — zabezpieczenie społeczeństwa.

Sprawiedliwościowa orientacja kodeksu w odniesieniu do ustawowego wymiaru kary była więc z tego względu przede wszystkim odpowiednio uzupełniona o wyraźnie indywidualnoprewencyjnie zorientowane zasady sędziowskiego wymiaru kary (art. 54 k.k.). Zasady te nie zaprzeczały klasycznemu rozumieniu kary, lecz je uzupełniały, pozwalając na szerokie uwzględnianie postulatów polityki kryminalnej i kryminologii przy wymiarze kary. Na ten aspekt kodeksu - sprawiedliwości w określaniu ustawowego wymiaru kary i indywidualnoprewencyjnie zorientowanego sędziowskiego wymiaru kary - zwracali szczególną uwagę badacze tacy jak Juliusz Makarewicz ${ }^{100}$. Okazywało się, że w praktyce zagadnienie sędziowskiego wymiaru kary, podporządkowane socjologicznej szkole prawa karnego, podobnie jak stosowanie środków zabezpieczających czy wyłączenie jako racji sędziowskiego wymiaru kary prewencji generalnej, budziło ogromne spory w orzecznictwie i pogłębiało różnice w poglądach sędziów. Odrębnym więc zagadnieniem badań było, w jaki sposób sędziowie odnoszą klasyczne zasady kary sprawiedliwej jako odpłaty za zawiniony czyn — ciągle dominujące przy określaniu podstawy ustawowego wymiaru kary - do prospektywnie zorientowanej przesłanki różnicowania sędziowskiego wymiaru kary przede wszystkim ze względu na właściwości indywidualnego sprawcy. W sensie prawniczym

98 Ibidem, s. 104-107.

99 Ibidem, s. 80.

100 Por. J. Makarewicz, Kodeks karny z komentarzem, Lwów 1938, s. 206-207. 
szczególnie brzemienna w dociekania mogła być wykładnia wyrażenia „przede wszystkim" w art. 54 k.k. z 1932 r.

VIII. Intrygujący temat sędziowskiego dochodzenia do sprawiedliwości kary został podjęty w badaniach prawnosocjologicznych przez Tomasza Kaczmarka oraz Tomasza Kaczmarka i jego zespół101. W serii publikacji poświęconych sędziowskiemu wymiarowi kary wskazano przede wszystkim na złożone psychospołeczne uwarunkowania wymiaru kary w perspektywie osoby sądzącego. Pierwszą $\mathrm{z}$ analiz oparto na badaniach ankietowych, w których wzięło udział 338 sędziów różnych szczebli ${ }^{102}$. W badaniach korzystano z siatki pojęciowej zaproponowanej przez Bronisława Wróblewskiego i Witolda Świdę w badaniach przedwojennych. Przede wszystkim nawiązano do wyróżnionych przez Wróblewskiego typów racjonalizacji kary ujmujących zagadnienie celów kary. Charakterystyczne, że te badania rozpoczynały się hipotezami dotyczącymi istoty i celów kary, które w swej początkowej fazie dopiero na drugim planie stawiały psychospołeczne czynniki determinujące postawę samego sędziego. Akcent w badaniach przesunął się na uwarunkowania psychospołeczne decyzji sędziego dopiero po ustaleniu wyraźnego zróżnicowania określeń istoty, sensu i celu kary dających się zrekonstruować z uzasadnień wyroków. Zaczęto wówczas poszukiwać powodów tego zróżnicowania w osobowości i światopoglądzie osób pełniących funkcję zawodową sędziego i w ich środowisku społecznym. Zastanawiano się, jakie i w jakich konfiguracjach występują zmienne istotne dla stanowiska sędziego w sprawie wymiaru kary, i jak mocno te właśnie zmienne osobowościowe oddziałują w poszczególnych typach przypadków.

W toku tych badań wyłonił się problem traktowania przez badanych sprawiedliwości jako zjawiska będącego w głównej mierze „sprawiedliwą odpłatą”. Problemem badawczym okazał się rygoryzm sędziów wobec sprawcy traktowanego w pewnych wypadkach jako niepoprawnego ze względu na cechy osobowości oraz potencjalny wpływ na niego środowiska kryminologicznie zdefiniowanego jako niekorzystne dla resocjalizacji ze względu na niski status społecznoekonomiczny. Przeciwieństwem rygoryzmu wobec tej kategorii sprawców była zalecana przez badanych reedukacja oparta na postawie tolerancji wobec drugiego typu sprawcy zdefiniowanego z góry jako tego, który „tylko pobłądził”, a którego wyższy status społeczny podnosił prawdopodobieństwo poprawy przyszłych zachowań. Już choćby na przykładzie tak różnie ukierunkowanego rygoryzmu

101 Przede wszystkim następujące publikacje: T. Kaczmarek, Sędziowski wymiar kary w PRL, Wrocław 1972; idem, Ogólne dyrektywy wymiaru kary w teorii i praktyce sqdowej, Wrocław 1980; T. Kaczmarek et al., Decyzja sędziego w sprawie wymiaru kary i jej psychospołeczne uwarunkowania, Wrocław 1987; T. Kaczmarek, Rozważania o przestępstwie i karze, Wrocław 2016.

102 T. Kaczmarek, Sędziowski wymiar... 
widać, że sprawiedliwa odpłata sama nie tłumaczy zjawiska sprawiedliwej kary rozumianej jako równe traktowanie ${ }^{103}$.

Spełnienie postulatu czystego obiektywizmu w wymiarze kary jest trudno osiągalnym przedmiotem starań. Realne jest raczej zachowanie kompromisu tak zwanej sprawiedliwej odpłaty za zawiniony czyn, preferencji ogólnoprewencyjnych i szczególnoprewencyjnych, który jest uznawany za pewną formę sprawiedliwości, w której są godzone interesy jednostki i społeczeństwa w mniej lub bardziej doskonałych proporcjach. Sednem sprawiedliwości kary jest ograniczanie dyskryminującego albo faworyzującego subiektywizmu, a więc bezpośrednio oddziałujących emocji i światopoglądu osoby wyrokującej, oderwanego od woli ustawodawcy i poczucia sprawiedliwości reprezentowanej społeczności. Taka interpretacja tej kwestii wskazuje na znacznie dojrzalsze ukształtowanie zasad sądowego wymiaru kary w art. 53 aktualnego k.k. niż w jednostronnie doktrynalnie określonych przesłankach jej wymiaru w art. 54 k.k. z 1932 r. W badaniach poświęconych karze i karaniu oraz zagadnieniu sprawiedliwości w odniesieniu do funkcji instytucji wymiaru sprawiedliwości kwestia psychospołecznego aspektu zachowań sprawcy przestępstwa zajmuje ważne miejsce. Jest ona analizowana w różnych dyscyplinarnych ujęciach i aktualizowana w związku z rozwojem nauk o człowieku. W przypadku sprawców przestępstw wątki psychospołeczne ujęte są w takich prawniczych określeniach, jak: ,pobudki sprawcy”, ,sposób działania sprawcy”, „,stosunek sprawcy do pokrzywdzonego”, „, charakter sprawcy”, ,zachowanie sprawcy po dokonaniu przestępstwa”. Mimo ogólnikowości tych sformułowań, ukierunkowują i systematyzują one pracę analityczną nad osądzanym czynem i sprawcą.

Nie powstał natomiast analogiczny słownik pozwalający na charakteryzowanie osób zawodowo sądzących w perspektywie zdolności do zobiektywizowanego, a więc w sensie potocznym — najbliższego sprawiedliwości — sądzenia ${ }^{104}$. Świadomość konieczności oceny stanu psychicznego i - w pewnym wymiarze — światopoglądu z leżącym u jego podstaw systemem norm i wartości osoby stającej w obliczu wymiaru sprawiedliwości wyprzedzała świadomość potrzeby obserwacji pod analogicznym kątem osób sądzących. Wpływ tych czynników na ocenę osądzanych zdarzeń odkrywano stopniowo, choć od dawna intuicja podpowiadała ludziom, że w sądzie wiele zależy od osoby sędziego ${ }^{105}$. Potwierdzają to określenia w rodzaju „dobry sędzia”, „sprawiedliwy sędzia”. Reformy kształcenia sędziów, wielokrotnie przeprowadzane w krajach europejskich, w tym także w Polsce, oparte na organizacji centralnego systemu kształcenia kandydatów na sędziego i dokształcania praktykujących sędziów, miały wśród swoich celów

103 Ibidem, s. 71-72; oraz też na ten temat cytowany także przez T. Kaczmarka A. Podgórecki, Prestiz prawa, Warszawa 1966.

104 T. Kaczmarek et al., Decyzja sędziego...

105 Por. T. Kaczmarek, Sędziowski wymiar..., s. 166-177. 
zapewnienie niezbędnej jednolitości orzecznictwa poprzez przyjęcie bardziej powszechnej, ogólnej kultury prawnej. To rozwiązanie miało uzupełniać tradycyjną unifikacyjną — a więc też — przynajmniej do pewnego stopnia motywowaną potrzebą sprawiedliwości - funkcję, jaką w tym zakresie mogła spełniać kontrola instancyjna wyroków ${ }^{106}$.

Obawy dotyczące dowolności wymiaru kary (miary i rodzaju[formy]) nie ze względu na cechy sądzonego czynu i właściwości sprawcy, lecz cechy osoby sądzącej, nie maleją także współcześnie. Rozmaitość jednostkowego wymiaru kary, nieznajdująca uzasadnienia w przedmiocie sprawy, jest niepokojąca z praktycznego punktu widzenia, gdyż wzmaga sytuację niepewności nie tylko w społeczeństwie, lecz także wśród samych sędziów. Właśnie oni z powodu złożonej natury spraw społecznych, z którymi mają do czynienia, muszą nieustannie poszukiwać nie tylko prawnego, lecz również społecznego i moralnego standardu oceny pewnych zjawisk. W niektórych przypadkach należy do nich także właśnie wyznaczanie norm społeczno-obyczajowych w nowych obszarach życia.

Do oceny wpływu osobowości sądzących na treść wyroków wiele wnoszą badania porównawcze przeprowadzane w ciągu wielu lat w różnych krajach ${ }^{107}$ oraz prowadzone w jednym kraju pod rządami różnych systemów prawa, zdeterminowanych zmianami ustrojów. Badania porównawcze należą do najtrudniejszych ze względu na dodatkowe parametry różnicujące porównywane zjawiska - na przykład zmienne kulturowe, językowe, ustrojowe. W Polsce analiza sędziowskiego wymiaru kary z perspektywy osobowości sędziego, jaka była prowadzona przez Tomasza Kaczmarka i jego zespół, wskazała daleko idące zmiany w postawach sędziów w ciągu długiego okresu mierzonego od czasu badań przeprowadzonych przez B. Wróblewskiego i W. Świdę ${ }^{108}$. Wielokrotnie zmieniło się nie tylko istotne $\mathrm{z}$ tego punktu widzenia zawodowe przygotowanie sędziów (co do treści i formy), lecz także odniesienie do ustawowych dyrektyw celów i wymiaru

106 Por. więcej na ten temat, J. Królikowska, J. Utrat-Milecki, The Criminal Judge in Poland in the Twentieth and Twenty-first Centuries. Empirical Studies, [w:] Legal Professions at the Crossroads, red. D. Jemielniak, Frankfurt am Main-New York 2014, s. 15-35.

107 Por. na temat tego typu badań i związanych z nimi trudności metodologicznych w szczególności D. Nelken, Comparative Criminal Justice, Los Angeles-London 2010; J. Pradel, Droit pénal comparé, Paris 2008. W naszej literaturze ciągle za klasyczne uznać można opracowanie J. Makarewicza, Prawo karne. Wykład porównawczy. Wykład Nelkena jest najbardziej kryminologiczny, Pradela mieszany, z silną ekspozycją zagadnienia prawa w działaniu, najmniej socjologiczny jest, co ciekawe, najstarszy ze wskazanych wykład Makarewicza zaliczanego do socjologicznej szkoły prawa karnego.

108 W części analitycznej badania prowadzone przez T. Kaczmarka zawierały bogatą prezentację poprzedzających je polskich i zagranicznych programów badawczych poświęconych zagadnieniom sędziowskiego wymiaru kary oraz badań o tematyce bliskiej kwestiom społecznego stosunku do przestępczości i karania oraz funkcjonowania systemu wymiaru sprawiedliwości. Zawierały się w tym liczne badania realizowane w kręgu badaczy Uniwersytetu Warszawskiego pod kierunkiem lub z inspiracji Adama Podgóreckiego. 
kary, kryteriów sprawiedliwości, a także relacja do opinii społecznej oceniającej działalność wymiaru sprawiedliwości i — rzecz jasna — sama ta opinia społeczna oraz kontekst ustrojowy.

Przegląd wytworzonej w ciągu lat literatury naukowej uzmysławia zmiany, jakie dokonały się nie tylko w systemie sprawiedliwości, lecz także w sądowym języku wyrażającym ocenę faktów społecznych odnoszących się do kary, karania i sprawiedliwego sądzenia. Duża zmiana dokonała się w zakresie języka, jakim sędziowie wypowiadają się na temat przestępstw i kar, a także w jakim dokonują oceny ustawodawstwa czy krytyki funkcjonowania wymiaru sprawiedliwości. W miejsce języka potocznego, emocjonalnego i nieścisłego, używanego przez sędziów-respondentów we wcześniejszych badaniach, wszedł język zaczerpnięty z opracowań naukowych. Widoczny jest dystans wobec niefachowych diagnoz i ocen na rzecz powoływania się na opinie biegłych specjalistów. O ile dawniej występowały odpowiedzi zawierające sformułowania odnoszące się do przestępców i przestępstw, jak „,wstręt do pracy”, „,bumelanctwo”, „,rozwydrzenie”, „złośliwość”, „bezczelność”, „niewyparzony język”, to w badaniach współczesnych takie wyrażenia są absolutnym wyjątkiem.

Także w odpowiedzi na pytanie dotyczące wzbogacenia środków represji karnej o środki nieprzewidziane w kodeksie nie ma już postulatu kary twierdzy, kolonii karnej dla niepoprawnych, pozbawienia obywatelstwa, jakie były w badaniach z 1937 r., oraz kary ciężkich robót publicznych, zesłania do domu pracy przymusowej, chłosty, jakie pojawiały się w badaniu z 1966 r. Po kilkudziesięciu latach, w badaniu z 2012 r., kara pręgierza była proponowana jeden raz ${ }^{109}$. Natomiast w badaniach T. Kaczmarka, których wyniki zostały opublikowane w roku 1972, wystąpiły propozycje sędziów, aby „,nieletnim szczególnie bezczelnie się zachowującym”, którzy jednak „nie powinni się stykać z atmosferą więzienia”, wymierzyć „parę tęgich batów na gołe pośladki w miejscu publicznym”. Argumentem przemawiającym za tym rozwiązaniem było stwierdzenie, że „zamykać ich żal ze względu na rodziców"110. Taki opis postępowania sądowo-wychowawczego byłby współcześnie trudny do zaaprobowania w publicznej wypowiedzi sędziego.

Klimat społeczny wokół postępowania z osobami naruszającymi normy prawne uległ poważnej zmianie i wiele typów kar oraz procedur karania nie jest stosowanych, a nawet uznawanych za możliwe do przywrócenia. Zmieniła się mówiąc językiem Bronisława Wróblewskiego — „kultura umysłowa” sędziów.

109 Kultury penalne. Kontekst kulturowy polityki kryminalnej i reform prawa karnego. Analiza prawno-penologiczna, historyczna, socjologiczna i kulturowa (antropologiczna) reform prawa karnego w Polsce na tle tendencji europejskich $i$ światowych (dec-2011/01/B/HS5/03206). W tych badaniach zespołu J. Utrat-Mileckiego prowadzonych przez J. Królikowską tylko jeden sędzia opowiedział się za przywróceniem kary pręgierza w małym miasteczku jako kary dyscyplinującej wybryki chuligańskie.

110 T. Kaczmarek, Sędziowski wymiar..., s. 210. 
Stali się oni bardziej świadomi zróżnicowania konsekwencji psychicznych wywieranych przez kary i są zdecydowani uwzględniać je już w samym wymiarze kary. Przede wszystkim deklarują ujmowanie kary w strukturze przyjętych typów racjonalizacji i unikanie tych, które ich standardu nie utrzymują w obszarze zakładanych celów indywidualnych i zbiorowych. Są także bardziej wrażliwi na bezwiedne współkaranie bliskich sprawcy i jego długoterminowe konsekwencje dla nich. W badaniach T. Kaczmarka są wyraźniejsze sygnały gotowości sędziów do formułowania własnych opinii na tle pewnych ogólnych teorii społeczeństwa i aktualnej wiedzy o człowieku. Odrzucane są przez sędziów propozycje wprowadzenia kar o nieokreślonych konsekwencjach i wielorakich skojarzeniach — na przykład piętnowanie sprawców wskutek nałożenia na nich obowiązku specjalnego oznakowania pojazdu lub nakazu publicznego noszenia znaków symbolizujących popełnienie pewnego rodzaju przestępstwa. Szczególną łagodzącą indywidualizację kary, dokonywaną przez respondentów biorących udział w badaniach z 1966 r., można dostrzec w przypadku przestępstw naruszających surowe prawo wizualizujące zasady ustrojowe państwa. $Z$ wypowiedzi respondentów wynika, że w ich decyzjach dotyczących spraw tak kontrowersyjnych, jak na przykład zakaz prywatnego handlu niewielką ilością dóbr, względy humanitarne wobec sprawców przeważały nad obroną abstrakcyjnych zasad systemowych. Respondenci chcieli zaprezentować się jako krytyczni wykonawcy prawa, którzy nie są tylko strażnikami systemu, lecz osobami odpowiedzialnymi za losy ludzkie. Byłaby to prawda, na którą powołał się Chaim Perelman, że: „sędzia nie jest sługą władzy, która go mianowała, ale sługą sprawiedliwości"'111.

Godna podkreślenia jest zmiana we współczesnym spojrzeniu na karę i jej funkcje wobec osób, które ją ponoszą i wobec społeczeństwa. O ile kilkadziesiąt lat temu nie budziło wątpliwości przekonanie, że skuteczność kary mierzy się brakiem powrotności do przestępstwa, to obecnie wiadomo, że sprawa powrotności jest determinowana przez wiele czynników, które nie mają bezpośredniego związku z odbytą karą ${ }^{112}$. Dostrzega się złożoność uwarunkowań społeczno-ekonomicznych i psychicznych tego zjawiska w powiązaniu z kierunkiem polityki karnej, nie definiując tej kwestii w kategoriach czysto behawioralnych. Współczesne społeczeństwa są pozbawione złudzeń co do istnienia prostych sposobów zwalczania przestępczości, gdyż poddały refleksji wiele swoich doświadczeń związanych z naruszaniem norm prawnych i są świadome konieczności dostosowywania swoich reakcji do zmian zachodzących w zbiorze czynników kryminogennych, naturze samych przestępstw oraz do aktualizowanej wiedzy o człowieku i jego skłonnościach ${ }^{113}$.

111 C. Perelman, op. cit., s. 123.

112 T. Kaczmarek, Sędziowski wymiar..., s. 188.

113 Ibidem, s. 211. 
Wiele problemów powracających w badaniach nad sprawiedliwością kary i karania bierze się z nieusuwalności różnego rodzaju napięć i sprzeczności naturalnie obecnych w codziennym życiu zbiorowości. Współwystępują tu dylematy wynikające z konieczności realizacji idei sprawiedliwości wyrażanej w ustawodawstwie, poczucia sprawiedliwości społeczeństwa (w tym takich szczególnych grup, jak ofiary i ich bliscy, a także osoby karane i ich bliscy) oraz przekonań sędziów. Sprawiedliwość kary z każdej z tych perspektyw może być różnie postrzegana i wpływać na zakres, w jakim może ona wypełniać cele przed nią stawiane. W gestii sędziów leży zapewnienie sprawiedliwości kary zarówno z perspektywy społeczeństwa, ofiary, jak i sprawcy. Co więcej, każda z tych stron relacji społecznej ma nie tylko inne wyobrażenia, lecz życzenia, które nie są adresowane do systemu, lecz do konkretnego sędziego. Wiele z tych właśnie dylematów pojawiło się $\mathrm{w}$ analizach przeprowadzonych $\mathrm{w}$ związku $\mathrm{z}$ badaniami prawnosocjologicznymi prowadzonymi w Polsce po drugiej wojnie światowej.

Przy całym krytycyzmie wobec stosowanej metodologii czy innych elementów postępowania $\mathrm{w}$ toku prowadzenia dotychczasowych badań na temat kary i karania oraz sprawiedliwości sądzenia trzeba brać pod uwagę istotne rezultaty osiągnięte w wyniku zadawania coraz wnikliwszych pytań i stawiania bardziej szczegółowych hipotez ${ }^{114}$. Wszystkie przeprowadzone badania pozostawiły nie tylko materiały dokumentalne, lecz także dały świadectwo stylu myślenia opracowujących je badaczy. Zebrane dane mogą być w dużych fragmentach powtórnie analizowane i poddane ocenie z perspektywy współczesnych technik oraz obecnej perspektywy teoretycznej. Zapewnienie porównywalności sędziowskiego wymiaru kary jest celem godnym realizacji trudnych programów badawczych, które obejmą wszystkie te problemy.

IX. Badania nad sędziowskim wymiarem kary prowadzone przez B. Wróblewskiego i W. Świdę, a następnie T. Kaczmarka z zespołem oraz warszawski krąg badaczy problemów socjologii prawa z A. Podgóreckim ${ }^{115}$ były kontynuowane w XXI wieku. Dalsze pytania dotyczące względów, jakimi kieruje się sędzia, podejmując decyzję w ramach sędziowskiego wymiaru kary, zostały postawione w badaniach prawnosocjologicznych przeprowadzonych przez Jadwigę Królikowską w ramach programu badawczego realizowanego w latach 2012-2015 przez zespół pod kierunkiem Jarosława Utrat-Mileckiego ${ }^{116}$.

W tych badaniach zwrócono uwagę na dosyć rozpowszechnione przekonanie, że sąd wymierza sprawiedliwość i udając się do niego, można oczekiwać obiektywnej oceny faktów oraz ich następstw, co zderza się z doświadczeniem

114 A. Podgórecki, op. cit., krytyka przeprowadzona w szczególności na s. 83-84.

115 M. Łoś-Bobińska, Zasady wymiaru sprawiedliwości w świetle badań empirycznych, „Etyka" 1968, nr 3.

116 Kultury penalne... 
ludzi rozczarowanych, którzy w różnych rolach mieli do czynienia z wymiarem sprawiedliwości. Traktowanie sprawiedliwości jako najwyższej wartości moralnej, a jednocześnie cechy pewnego zorganizowanego systemu działań społecznych (wymiaru sprawiedliwości) sprawia, że system ten stara się stworzyć sformalizowane procedury zabezpieczające realizację tej wartości. Jak każdy zbiurokratyzowany system - ma swoje zalety, lecz także pewne wady, z których wynika słabe lub wręcz czasami pozorne realizowanie zakładanych celów. Wszelkie sytuacje, w których można zidentyfikować działanie systemu zaniedbujące albo naruszające wartość, jaką jest sprawiedliwość, są wskazywane jako wymagające interwencji naprawczej.

W tych badaniach, prowadzonych pod kierunkiem Jarosława Utrat-Mileckiego i Jadwigi Królikowskiej, przeprowadzonych z udziałem 160 sędziów-respondentów i 12 sędziów-rozmówców, zadawano wiele pytań dotyczących sprawiedliwości, w tym sprawiedliwego karania. Jednym z najważniejszych pytań zadanych podczas wywiadów było: „Czy sąd wymierza karę czy sprawiedliwość?”. Jedna z rozmówczyń odpowiedziała:

Chyba jednak sprawiedliwość. Bo — jeżeli jest taka możliwość — to [w wyroku] nie zawsze musi być kara. Czasami bardziej istotne niż wymierzenie samej kary jest ustalenie, że ktoś jest sprawcą. Kara nie zawsze musi się łączyć z wymiarem sprawiedliwości, kara jest jakby drugim elementem, który jest istotny w naszym wymiarze sprawiedliwości. Istotne jest ustalenie prawdy, zdarzenia faktycznego i ustalenie sprawcy, czy ktoś popełnił dany czyn, czy nie.

Rozwijając tę myśl w odpowiedzi na pytanie „Czy uważa, że sprawiedliwość jest dla ludzi ważna?”, sędzia odpowiedziała zdecydowanie:

Tak, każdy chce sprawiedliwości. Przecież po to przychodzi się do sądu, a nie tylko w sprawach karnych. Każdy przychodzi po sprawiedliwość i nawet ci najciężsi przestępcy domagają się od sądu sprawiedliwego wyroku. Nie mówią, proszę o łagodną karę, tylko chcą, aby wyrok był sprawiedliwy i myślę, że to jest istota tego zdarzenia, tego naszego sprawowania tej władzy [sądowniczej].

Podobne przekonanie żywi inny rozmówca, który na pytanie „Czy sąd wymierza karę czy sprawiedliwość”, odpowiedział: „Jednak chyba sprawiedliwość, poprzez karę, ale sprawiedliwość". Następny na to samo pytanie odpowiedział: „Wymiar kary jest wymiarem sprawiedliwości, to nie są pojęcia, które funkcjonują niezależnie od siebie, a więc wymiar kary jest wymiarem sprawiedliwości”. W podobnym duchu wypowiedział się inny rozmówca, który stwierdził: „Wymierza się z zasady karę, a kara musi być sprawiedliwa. Dlatego to jest wymiar sprawiedliwości". Pytanie o sprawiedliwość karania nie było dla sędziów neutralne, budziło ich żywą reakcję. Czasem wywoływało głębszą refleksję, jak w przypadku sędziego, który rozpoczął swoją odpowiedź zdecydowanym stwierdzeniem: 
„Sędzia wymierza sprawiedliwość”. Po chwili uznał, że właściwiej będzie, jeśli powie: „Sędzia rozstrzyga sprawę najbardziej sprawiedliwie w oparciu o aktualnie obowiązujące przepisy".

Współczesne rozważania teoretyczne o istocie i funkcji kary w powiązaniu z wynikami empirycznych badań prawnospołecznych odnoszących się do sprawiedliwości w ogólności, lecz przede wszystkim do sprawiedliwości karnej, w istotny sposób uzupełniają aktualny dyskurs polityczno-kryminalny, który jest zdominowany przez tradycyjne ujęcia kryminologiczne. Dyskurs ten jednostronnie koncentruje się w naturalny dla siebie sposób przede wszystkim na funkcji ochronnej prawa karnego. Jest wiele argumentów przemawiających za tym, że funkcja ta ma sens i legitymizm ustrojowy tylko wtedy, kiedy służy sprawiedliwości ${ }^{117}$.

W XX wieku, kiedy nauki społeczne obudziły wielkie nadzieje związane $\mathrm{z}$ badaniem różnych aspektów życia społecznego nowymi metodami empirycznymi, zaczęto z ich udziałem na szerszą skalę realizować programy badawcze dotyczące problemów prawa. Wprawdzie wspomniane badania stawiały jako główny problem badawczy kwestię sędziowskiego wymiaru kary, jednak w jego tle było pytanie o jej sprawiedliwość, szczególnie w kontekście przyjmowanego porządku racjonalizacji kary. Badania te i oparte na nich analizy rozszerzały tradycyjne spojrzenie kryminologiczne i prawnokarne na sędziowski wymiar kary między innymi o ogólną socjologiczną refleksję na temat istoty i roli sprawiedliwości. Zwracały uwagę na znaczenie tej wartości w życiu społecznym oraz eksponowały trudności z dochodzeniem do niej w sformalizowanych procedurach wymiaru sprawiedliwości.

Podobnie traktują wątek sprawiedliwości przeprowadzone przez nas badania prawnosocjologiczne zrealizowane w ramach programu badawczego Narodowego Centrum Nauki ${ }^{118}$. Kwestia kształtowania sprawiedliwości kary kryminalnej towarzyszyła w tym badaniu szerszemu zagadnieniu charakterystyki czynników determinujących sędziowski wymiar kary pod rządami aktualnego kodeksu karnego. Cechą szczególną tych badań było oparcie ich świadomie na założeniach teorii i metod badań integralnokulturowych, co pozwalało na przyjęcie w nich zarówno perspektywy teoretycznej, przyjmowanej w analizach prawnych, jak i perspektywy socjologicznej z jej akcentami na społeczne generowanie zjawisk prawnych ${ }^{119}$. Oznaczało to traktowanie kary kryminalnej jako instytucji prawnej i społecznej, która jak każde naznaczone etycznością działanie ludzkie jest określona zarówno

$117 \mathrm{~W}$ kontekście europejskim zagadnienie to z perspektywy integralnokulturowej zostało przedstawione w opracowaniu: J. Utrat-Milecki, The effects of the civilizing...

118 Program badawczy NCN Kultury penalne.

119 Por. Badania integralnokulturowe, [hasło w:] Encyklopedia pedagogiczna XXI wieku, red. T. Pilch, Suplement, Warszawa 2010; S. Juszczyk, Badania jakościowe w naukach społecznych. Szkice metodologiczne, Katowice 2013, s. 187. 
w przepisach prawa, jak i kulturowych wzorach organizacyjnych praktyk wymiaru sprawiedliwości karnej. Badanie kary kryminalnej powinno więc uwzględnić wszystkie elementy, które współokreślają jej kształt faktyczny i pożądany ukazujący się na każdym etapie postępowania w sprawie karnej.

Przyjęcie na początku XXI wieku perspektywy integralnokulturowej w badaniach na temat kary i karania wiązało się z adaptacją do pytań badawczych wyróżnionych w ramach tej koncepcji elementów definicyjnych kary kryminalnej. Rozszerzona definicja kary kryminalnej, stanowiąca podstawę teorii kary, brzmi następująco:

karą kryminalną nazywamy działania społeczne ze sfery kontroli społecznej zaspokajające potrzeby osób i zbiorowości w zakresie poczucia ładu społecznego, sprawiedliwości i bezpieczeństwa, posiadające zasadę naczelną, czyli zamiary i cele, które stanowią podstawę ich racjonalizacji, normy oraz personel i urządzenia materialne, a także funkcje społeczne rozumiane jako ich uświadomione i nieuświadomione konsekwencje (typowe), podjęte w formach organizacyjnych, podlegających instytucjonalizacji w przepisach prawa i decyzjach sądów oraz innych uprawnionych organów państwa, jeśli wyczerpują następujące znamiona:

- opierają się na uznaniu wolnej woli podmiotu oddziaływań;

- są odpowiedzią na ściśle zdefiniowany wcześniej w prawie czyn podmiotu, naruszający w sposób dolegliwy ład społeczny in abstracto i in concreto;

— są odpowiedzią na winę, czyli na zarzucalne sprawstwo podmiotu oddziaływań;

- zakładają ostateczne uznanie winy podmiotu przez uprawniony autorytet (sąd), w sposób zgodny z przyjętymi wcześniej procedurami;

— są podejmowane na podstawie przyzwolenia, by wobec podmiotu stosować w stopniu nadzwyczajnym przymus i przemoc fizyczną;

— są częścią procesu świadomego zadawania podmiotowi dolegliwości przez pozbawianie go cenionych społecznie dóbr;

— wyrażają potępienie podmiotu, które znajduje wyraz w zerwaniu z nim dotychczasowych więzi społecznych i wpływa negatywnie na możliwość i sposób realizacji jego uprawnień;

- wiążą ocenę zarzucanego podmiotowi czynu i wymiaru wyrażanego potępienia oraz zadawanej mu dolegliwości z prawdziwymi założeniami aksjologicznymi naruszonego ładu;

— opierają się na zinstytucjonalizowaniu miary dla zadawanych dolegliwości;

- przewidują reguły publicznego pojednania z podmiotem oddziaływań, determinujące podejmowanie prób umożliwienia mu powrotu do stanu normalnego funkcjonowania w społeczeństwie;

— zakładają uznanie prawa łaski ${ }^{120}$.

Zrozumiałe jest, że problemy badawcze wynikające z szerokiego, integralnokulturowego określenia istoty kary kryminalnej muszą być podejmowane stopniowo i we wzajemnym powiązaniu. Należy podkreślić, że wymaga to obserwowania procesualności kary i wynikania jej stadiów z poprzedzających faz oraz

120 Por. J. Utrat-Milecki, Podstawy penologii..., s. 78-81. Pierwsza wersja integralnokulturowej rozszerzonej definicji kary kryminalnej została opublikowana wcześniej, por. J. Utrat-Milecki, Kontekst kulturowy koncepcji penologicznych, [w:] System penitencjarny i postpenitencjarny w Polsce, red. T. Bulenda, Warszawa 2003, s. 36-76. 
sposobu komponowania się jej części składowych z innymi elementami tej instytucji społecznej ${ }^{121}$. Stworzy to obraz dokładniejszy i bardziej zrozumiały, także z perspektywy faktycznych i zakładanych celów, i funkcji oraz racjonalizacji, jakie nadaje się zjawisku kary kryminalnej. Należy wskazać, że takie integralnokulturowe spojrzenie na karę kryminalną znalazło już istotne uznanie w głównym nurcie polskiej nauki prawa karnego, o czym przesądza też stanowisko samego Tomasza Kaczmarka w tej sprawie ${ }^{122}$. Badania integralnokulturowe jako podejście interdyscyplinarne do badań wymiaru sprawiedliwości karnej znalazło też już szersze uznanie $w$ ramach pedagogiki resocjalizacyjnej ${ }^{123} i$ penitencjarysty$\mathrm{ki}^{124}$. Jak wskazaliśmy w tym artykule w nawiązaniu do długiej tradycji — od badań Bronisława Wróblewskiego, Witolda Świdy do badań Tomasza Kaczmarka i jego zespołu — w penologii podejście integralnokulturowe stanowić może również dobrą podstawę teoretyczną do badań zagadnienia sprawiedliwości w toku sądowego ustalania następstw czynu zabronionego pod groźbą kary kryminalnej.

\section{Punishment and justice in the judge's sentencing decisions}

\section{Summary}

The article starts with the general presentation of the sociological perspective on the question of justice in the motives of a criminal judge's sentencing decisions. The question of justice is also analysed in relation to the legitimation of the criminal law and the various theories of punishment, retributive, consequentialist, and mixed. Punishment is analysed as a social and legal institution and as a social process in its various organisational forms. The rationalisation of punishment as a social and legal institution is analysed in relation to the question of human rights, and the question of its effectiveness in social control as a tool in the protective function of the criminal law. The problem of justice is also analysed from a subjective point of view as a question of the just judge. It is not only analysed here as an ethical question, but also as a problem of the methodology of the work of the judge, and a question of organisation of the sentencing process. The article presents the results of research (sociological reports) concerning the question of the motives of judges' sentencing in the criminal courts. The article presents the basics of the methodology and results of research in that respect which was carried out in the 1930s (B.Wróblewski, W. Świda), 60s and 70s (T. Kaczmarek, W. Świda), and the 1980s (T. Kaczmarek, J. Giezek and the team), and the latest research carried out by the authors in 2012-2015 (J. Królikowska, J. Utrat-Milecki). The authors explain here the general outline of the method of culturally integrated (social and legal) studies,

$121 \mathrm{Na}$ konieczność spojrzenia na karę kryminalną z szerszej procesualnej perspektywy zwracała w polskiej nauce prawa karnego szczególną uwagę Genowefa Rejman (eadem, Wprowadzenie, [w:] Kodeks karny. Część ogólna. Komentarz, red. G. Rejman et al., Warszawa 1999, s. 13), por. też J. Utrat-Milecki, Prawo karne i polityka kryminalna ..., s. 72-75 n.

122 Por. T. Kaczmarek, Pojęcie kary kryminalnej i jej kulturowo-historyczne uwarunkowania, [w:] System Prawa Karnego, t. 5. Nauka o karze. Sadowy wymiar kary, red. T. Kaczmarek, Warszawa 2015, s. 12-35. M. Sztuka, op. cit.

123 Por. M. Sztuka, op. cit.

124 Polski system penitencjarny. Ujęcie integralno-kulturowe, red. P. Szczepaniak, Warszawa 2013. 
which they used in their sociological and anthropological research on the criminal justice officers (judges, prosecutors and probation officers), and which is also the theoretical background of the present article. Finally, the authors present the broader culturally integrated definition of punishment, so as to help to identify the main research questions in socio-legal studies of punishment considered both as a socio-legal institution and a social and legal process which can be identified in different organisational forms.

Keywords: punishment, justice, criminal justice system, judge, penology, social and legal institution, sentencing, culturally integrated (social and legal) studies, human rights, social control. 